Research Article

\title{
Acute Toxicity, Antioxidant, and Antifatigue Activities of Protein-Rich Extract from Oviductus ranae
}

\author{
Yang Zhang $\mathbb{D},{ }^{1,2}$ Yang Liu $\left(\mathbb{D},{ }^{1}\right.$ Kun Zhu $\mathbb{D},{ }^{3}$ Yao Dong $\mathbb{D}^{4}{ }^{4}$ Hao Cui $\mathbb{D},{ }^{1,2}$ Liping Mao $\mathbb{D},{ }^{1}$ \\ Xiaoxiao Xu $\mathbb{1}^{1},{ }^{1}$ and Hongli Zhou $\mathbb{1}^{1,2}$ \\ ${ }^{1}$ School of Chemistry and Pharmaceutical Engineering, Jilin Institute of Chemical Technology, Jilin 132022, China \\ ${ }^{2}$ Jilin Engineering Research Center for Agricultural Resources and Comprehensive Utilization, Jilin Institute of Chemical Technology, \\ Jilin 132022, China \\ ${ }^{3}$ Department of Pharmacy, China-Japan Union Hospital of Jilin University, Changchun 130013, China \\ ${ }^{4}$ School of Biology and Food Engineering, Jilin Institute of Chemical Technology, Jilin 132022, China
}

Correspondence should be addressed to Hongli Zhou; zhouhongli@jlict.edu.cn

Received 31 October 2017; Revised 9 January 2018; Accepted 16 January 2018; Published 25 February 2018

Academic Editor: Ilaria Peluso

Copyright (c) 2018 Yang Zhang et al. This is an open access article distributed under the Creative Commons Attribution License, which permits unrestricted use, distribution, and reproduction in any medium, provided the original work is properly cited.

\begin{abstract}
The paper investigated the preparation, amino acid composition, acute toxicity, and in vitro and in vivo antioxidant, coupled with in vivo antifatigue activities of protein-rich extract of Oviductus ranae (PEOR). The results indicated that PEOR possesses highsafety property with maximum tolerated dose (MTD) higher than $20 \mathrm{~g} / \mathrm{kg}$ in mice, shows weak scavenging capacities against hydroxyl, superoxide anion, and 1,1-diphenyl-2-picrylhydrazyl (DPPH) radicals, as well as ferric-reducing antioxidant power in vitro, but exerts strong antioxidant effect in ethanol-induced oxidative stress mice model; it can decrease malonaldehyde (MDA) and protein carbonyl (PCO) formation and increase total superoxide dismutase (T-SOD) activity and glutathione (GSH) synthesis. Besides the strong in vivo antioxidant activity, PEOR in a dose of $400 \mathrm{mg} / \mathrm{kg}$ also has antifatigue effect in mice, and it can prolong the exhaustive swimming time, reduce the elevated blood urea nitrogen (BUN) and blood lactic acid (BLA) caused by intense exercise. The in vivo activity of PEOR may be contributed by its absorbed amino acids, due to the fact that eight antioxidant amino acids and twelve glucogenic ones were found in it. This study will provide an evidence for the clinical use of PEOR as a dietary supplement for antioxidant and antifatigue in the same oral dose (400 mg/kg).
\end{abstract}

\section{Introduction}

Some harmful factors including overconsumption of drinking and smoking, X-ray irradiation, organic pollutants, and heavy metals can cause the overproduction of reactive oxygen species (ROS), which subsequently destroy the dynamic equilibrium between ROS generation and elimination to induce oxidative stress [1]. Moreover, under the physiological condition of oxidative stress, excess ROS can directly react with protein and DNA, as well as lipid to damage their structures and functions [2], leading to cell death and aging [3], coupled with some diseases, such as inflammation [4], immune deficiency [5], Parkinson's disease [6], Alzheimer's disease [7], and cancer [8]. Due to the fact that levels or activities of endogenous antioxidants, such as glutathione (GSH), superoxide dismutase (SOD), glutathione peroxidase (GPx), and catalases (CAT), are always lower than the level demanded for free radical-scavenging, it is usually necessary to supplement exogenous antioxidant when facing oxidative stress [9]. Another critical role of antioxidant lies in its positive effects on chronic fatigue syndrome (CFS) [10]. An increasing number of papers have demonstrated that antioxidant also exerts antifatigue activity in vivo, especially for some natural products [11-14].

Proteins are a kind of macromolecular substances consisting of different amino acids, which were found 
throughout most organs and tissues in the body. In addition to innate physiological functions comprising biological catalysis, DNA replication, muscle contraction, and molecules transportation [15], they also exhibit diverse biological activities, and antioxidant activity is one of the beneficial functions for human beings [16-18].

The Chinese brown frog, Rana chensinensis, is one of the famous economic animals farmed in China. It belongs to small amphibious frog with the mature male body size of $52 \sim 64 \mathrm{~mm}$ and female of 58 64 mm [19]. The natural populations of $R$. chensinensis mainly distribute in wet woodlands and mountains at low altitude ranging from $600 \mathrm{~m}$ to $1300 \mathrm{~m}$ in Northeastern China. In 1987, the wild R. chensinensis was listed as one of the national key-protected wild medicinal materials by the Chinese government, and its artificial breeding achieved large-scale reproduction in the 1990s [20, 21]. The economic value of $R$. chensinensis mainly depends on its dried oviduct, Oviductus ranae (OR), a traditional Chinese medicine (TCM) used in China for hundreds of years. OR was originally described in Compendium of Materia Medica in the Ming dynasty and listed in Chinese Pharmacopeia since 1985 [22]. Traditionally, OR was consumed as a tonic for the remedies of debilitation, insomnia, neurasthenia, respiratory symptoms, and climacteric syndrome [23]. Modern pharmacological studies have revealed that OR displays a wide range of activities including immune-enhancement [24], antiaging [25], antifatigue [26], antioxidation [27], antiosteoporosis [28], and estrogen-like effects [29]. OR is composed of proteins, lipids, steroids, vitamins, nucleic acids, and trace elements [30]; among them, proteins are the main constituents present in it; in most cases, their contents are more than $50 \%$ [24].

A great number of basic and experimental studies regarding oxidative stress have been performed to reveal the probable mechanisms involving the regulation of the imbalance between prooxidant and antioxidant system. These mechanisms provided major insights into oxidative stress and have advanced the clinical trials and approaches, resulting in successful prevention and diagnosis, as well as therapies [31]. Many natural antioxidants based on plants and other living organisms have been scientifically confirmed as effective therapeutic agents. Moreover, with the increase of healthy lifestyle pursuit, more and more people have consumed the natural antioxidants routinely. Furthermore, some individuals, especially athletes and sport professionals, are also eager for the antioxidant-possessing antifatigue functions. To date, numerous papers have reported the antioxidant activities of extracts or isolated compounds from TCM, which has become one of the most abundant sources of novel antioxidant discovery [32]. It is therefore important to obtain efficient natural antioxidants that can also exert antifatigue activities without any damages on the healthy consumers from TCM. OR is a precious TCM with high protein content, but, to our knowledge, there is little information on the antioxidant-related activities of proteins in it. Thus, in present study, with the aim at obtaining the potential of proteins from OR for becoming an antioxidant supplement with highsafety property. The protein-rich extract from OR (PEOR) was prepared and analyzed, and the acute toxicity and in vitro and in vivo antioxidant activities of PEOR were assessed. Then the in vivo antifatigue effect of PEOR was further evaluated.

\section{Materials and Methods}

2.1. Materials. OR samples were obtained from Jilin Huangzhihua Pharmaceutical Co. Ltd (Jilin, Changchun, China) and identified by Prof. Guangshu Wang, School of Pharmaceutical Sciences, Jilin University (Jilin, Changchun, China). Specimen of OR (voucher number HG-2035) was preserved in Jilin Engineering Research Center for Agricultural Resources and Comprehensive Utilization, Jilin Institute of Chemical Technology (Jilin, Jilin, China).

Ginsenoside (2.5 mg of Rg3 per $100 \mathrm{mg}$ ) was from Dalian Fusheng Pharmaceutical Co. Ltd (Liaoning, Dalian, China). The bovine serum albumin (BSA) was purchased from Nanjing Jiancheng Biotechnology Co. Ltd (Jiangsu, Nanjing, China). The majority of chemicals used for the in vitro antioxidant evaluation were obtained from Civi Chemical Technology Co. Ltd (Shanghai, China) including 1, 10-phenanthroline, vitamin C (VC), 1, 1-diphenyl-2-picrylhydrazyl (DPPH), nicotinamide adenine dinucleotide (NADH), nitroblue tetrazolium (NBT), and phenazine methosulphate (PMS). Other solvents and reagents were analytical grade and provided by Sigma Aldrich Chemical Co. Ltd (St. Louis, MO, USA).

Amino acid mixture standard solution including glycine, L-alanine, L-cystine, L-methionine, L-leucine, L-isoleucine, L-valine, L-glutamic acid, L-aspartic acid, L-phenylalanine, L-arginine, L-lysine, L-threonine, L-histidine, L-tyrosine, Lserine, L-proline, and ammonium chloride was obtained from Wako Pure Chemical Industries Ltd (Tokyo, Japan).

Biochemical indicators including aspartate transaminase (AST), alanine transaminase (ALT), glucose (GLU), triglycerides (TG), creatinine (CRE), and blood urea nitrogen (BUN) were determined by an AU2700 Beckman coulter chemistry analyzer (Beckman Coulter, Brea, CA, USA).

Reagent kits for the determination of malonaldehyde (MDA), total superoxide dismutase (T-SOD), glutathione (GSH), protein carbonyls (PCO), BUN and hepatic glycogen (HG) were obtained from Jiancheng Biotechnology Co. Ltd (Nanjing, Jiangsu, China).

Blood lactic acid (BLA) was determined by a Lactate Scout+ analyzer (EKF Diagnostics, Cardiff, WAL, England).

2.2. Preparation of PEOR. Prior to experiment, OR samples were grinded into power and sieved to 100 mesh. PEOR was prepared according to the reported method [24] with some modifications. About $10 \mathrm{~g}$ of OR powers were soaked in $1000 \mathrm{ml}$ of phosphate buffered saline (PBS) solution ( $\mathrm{pH}$ 6.5) at room temperature for $12 \mathrm{~h}$, treated with ultrasonic wave at a power of $300 \mathrm{~W}$ for $2 \mathrm{~h}$ (Voshin, VS-200UE, Jiangsu, China). Then the mixture was centrifuged at $4500 \mathrm{rpm}$ for $20 \mathrm{~min}$ at $4^{\circ} \mathrm{C}$, the supernatant was filtered using a hollow-fiber membrane $(0.45 \mu \mathrm{m}$, GE Healthcare Life Sciences, Pittsburgh, PA, USA), and the precipitant was extracted twice as the above-mentioned method. The filtrate was mixed with ammonium sulfate ( $80 \%$ saturation) to 
produce precipitant, which was dissolved in distilled water and dialyzed for $24 \mathrm{~h}$ (MD10, Viskase, Darien, IL, USA). The dialysate was centrifuged at $4500 \mathrm{rpm}$ for $20 \mathrm{~min}$ at $4^{\circ} \mathrm{C}$, then the supernatant was freeze-dried, giving $1.02 \mathrm{~g}$ of PEOR, and the extraction yield was $10.2 \%$.

2.3. General Chemical Analysis. Protein content of PEOR was determined by Bradford method using BSA as standard [33]. Moisture was determined via drying PEOR in an oven at $105^{\circ} \mathrm{C}$ for $6 \mathrm{~h}$, and ash was determined by heating PEOR overnight at $550^{\circ} \mathrm{C}$. Lipid content of PEOR was determined by Soxhlet method using petroleum ether as solvent $[21,34,35]$.

2.4. Amino Acid Composition of PEOR. $50 \mathrm{mg}$ of PEOR was mixed with $5 \mathrm{ml}$ of $6 \mathrm{~N}$ hydrochloric acid at $110 \pm 1^{\circ} \mathrm{C}$ for $24 \mathrm{~h}$ under the protection of nitrogen atmosphere [36]. Before analysis, the $\mathrm{pH}$ value of hydrolysate solution was adjusted to 2.2 with $4 \mathrm{~mol} / \mathrm{l} \mathrm{LiOH}$. Then the amino acid composition was analyzed by a fully automated amino acid analyzer (L-8900 Hitachi, Tokyo, Japan). The analytical conditions were as follows: chromatographic column, cation exchange resin $4.6 \mathrm{~mm} \times 60 \mathrm{~mm}$; temperature of column oven, $57^{\circ} \mathrm{C}$; mobile phase, citric acid-sodium citrate at a flow rate of $0.25 \mathrm{ml} / \mathrm{min}$; chromogenic agent, ninhydrin solution at a flow rate of $0.125 \mathrm{ml} / \mathrm{min}$; temperature of derivatization, $135^{\circ} \mathrm{C}$; sample size, $20 \mu \mathrm{l}$; detection wavelength, $570 \mathrm{~nm} /$ $440 \mathrm{~nm}$.

\subsection{Animals and Acute Toxicity of PEOR}

2.5.1. Experimental Animals. SPF-graded ICR mice (aged 4 weeks, weighing $20 \pm 2 \mathrm{~g}$, half male and half female) were purchased from the Experimental Animal Center of Jilin University (approval number SCXK (Ji) 2008-0005, Jilin, Changchun, China). Animals were feed in polypropylene cages and allowed free access to food and water. The rearing conditions were as follows: temperature of $20 \pm 2^{\circ} \mathrm{C}$, relative humidity of $60 \pm 10 \%$, and a $12 \mathrm{~h}$-light/dark regime. Animal experiments were conducted based on the National Institutes of Health Guide for the Care and Use of Laboratory Animals (NIH publications number 8023, revised 1978) and approved by the Animal Care and Welfare Committee of Jilin Institute of Chemical Technology.

2.5.2. Acute Toxicity of PEOR. Acute toxicity evaluation was conducted based on the guideline of Organization for Economic Cooperation and Development (OECD) for acute oral toxicity and previous work $[21,37]$ with some modifications. Eighty mice (half male and half female) were randomly divided into four groups (20 in each group, in each group 10 per sex); prior to administration, animals were fasted for $12 \mathrm{~h}$ and had free access to water. PEOR was dissolved in distilled water $(3 \mathrm{ml} / 100 \mathrm{~g} \mathrm{BW})$ and orally treated to mice in doses of $5 \mathrm{~g} / \mathrm{kg} \mathrm{BW}$ (administration once), $10 \mathrm{~g} / \mathrm{kg} \mathrm{BW}$ (administration twice in $12 \mathrm{~h}$ ), and $20 \mathrm{~g} / \mathrm{kg} \mathrm{BW}$ (administration three times in $24 \mathrm{~h}$ ); mice in normal control (NC) group were orally treated with equal amount of distilled water. After a single dose administration, mortality and clinical signs associated with toxicity were observed and recorded daily for consecutive two weeks; body weight changes were measured before and after administration on the 14th day.

On day 14, after being weighed, animals were fasted for $12 \mathrm{~h}$ (free access to water) and anesthetized with pentobarbital sodium in a dose of $50 \mathrm{mg} / \mathrm{kg} \mathrm{BW}$ intraperitoneally. Blood samples were collected from orbit into nonheparinized Eppendorf tubes for the determination of serum biochemical parameters including AST (substrate method), ALT (substrate method), GLU (hexokinase method), TG (GPO-PAP method), CRE (sarcosine oxidase method), and BUN (urease/glutamate dehydrogenase method) using an AU2700 Beckman coulter chemistry analyzer (Beckman Coulter, Brea, CA, USA). Then animals were euthanized with carbon dioxide, and a complete necropsy was performed. Some vital organs comprising liver, spleen, kidney, and testes/ovaries were harvested and weighed. Relative organ weight was calculated according to the following formula:

$$
\text { Relative organ weight }(\%)=\frac{\text { organ weight }}{\text { body weight }} \times 100 \text {. }
$$

Organs collected from animals were preserved in formalin solution (10\%, $\mathrm{pH} 7.4)$ for the further histopathologic examination.

\subsection{In Vitro Antioxidant Activity of PEOR}

2.6.1. Hydroxyl Radical-Scavenging Assay. Hydroxyl radicalscavenging assay of PEOR was conducted based on the method reported by You et al. [38] with some modifications. PEOR samples were dissolved in distilled water to prepare solutions at different concentrations $(2,4,6,8$, and $10 \mathrm{mg} / \mathrm{ml}$ ). $2 \mathrm{ml}$ of PEOR solution and $1 \mathrm{ml}$ of PBS solution containing $0.75 \mathrm{mmol} / \mathrm{l} 1,10$-phenanthroline ( $\mathrm{pH} 7.4$ ) were mixed together. Subsequently, $1 \mathrm{ml}$ of $0.75 \mathrm{mmol} / \mathrm{FeSO}_{4}$ and $1 \mathrm{ml}$ of $\mathrm{H}_{2} \mathrm{O}_{2}$ solution $(0.12 \%, v / v)$ were added. After being incubated at $37^{\circ} \mathrm{C}$ for $60 \mathrm{~min}$, the absorbance of mixture $\left(\mathrm{A}_{\mathrm{s}}\right)$ was determined at $536 \mathrm{~nm}$ using an UV-visible spectrophotometer (722 N, Jingke Scientific Instrument Co. Ltd., Shanghai, China). The other two reaction systems in the absence of $\mathrm{H}_{2} \mathrm{O}_{2}$ and PEOR samples were used as normal control $\left(\mathrm{A}_{\mathrm{c}}\right)$ and blank $\left(\mathrm{A}_{0}\right)$ solutions, respectively. $\mathrm{VC}$ at concentrations of $0.01,0.02,0.03,0.04$, and $0.05 \mathrm{mg} / \mathrm{ml}$ were used as positive control. The hydroxyl radical-scavenging rate was calculated as the following formula:

$$
\begin{aligned}
& \text { Hydroxyl radical - scavenging rate }(\%) \\
& \qquad=\left(A_{s}-A_{0}\right) \times \frac{100}{\left(A_{c}-A_{0}\right)} .
\end{aligned}
$$

2.6.2. DPPH Radical-Scavenging Assay. DPPH radicalscavenging activity of $\mathrm{PEOR}$ was determined using the previously reported method [39] with some modifications. PEOR samples were dissolved in distilled water to prepare solutions at concentrations of $2,4,6,8$, and $10 \mathrm{mg} / \mathrm{ml}$. $2 \mathrm{ml}$ of PEOR solution and $2 \mathrm{ml}$ of $0.1 \mathrm{mmol} / \mathrm{l} \mathrm{DPPH}$ ethanol solution were mixed and reacted in the dark for $30 \mathrm{~min}$ at room temperature. Then the absorbance of the mixture was measured at $517 \mathrm{~nm}\left(\mathrm{~A}_{\mathrm{s}}\right)$. The reaction system in the absence of DPPH was used as normal control $\left(A_{c}\right)$, system in the absence of 
PEOR used as blank solution $\left(\mathrm{A}_{0}\right)$. VC at concentrations of $0.02,0.04,0.06,0.08$, and $0.1 \mathrm{mg} / \mathrm{ml}$ was used as positive control. The DPPH radical-scavenging rate was calculated by the following equation:

$$
\begin{aligned}
& \text { DPPH radical - scavenging rate }(\%) \\
& =\left(A_{s}-A_{c}\right) \times \frac{100}{A_{0}} .
\end{aligned}
$$

2.6.3. Superoxide Anion Radical-Scavenging Assay. Superoxide anion radical-scavenging activity of PEOR was assessed by the method reported by Li et al. [40] with some modifications. PEOR samples were dissolved in distilled water to prepare solutions at concentrations of $1,2,3,4$, and $5 \mathrm{mg} / \mathrm{ml}$. $1 \mathrm{ml}$ of PEOR solution and $3 \mathrm{ml}$ of Tris- $\mathrm{HCl}$ buffer ( $16 \mathrm{mmol} / \mathrm{l}, \mathrm{pH} 8.0)$ containing $0.5 \mathrm{ml}$ of $\mathrm{NADH}$ solution $(470 \mu \mathrm{mol} / \mathrm{l})$ and $0.5 \mathrm{ml}$ of NBT solution $(300 \mu \mathrm{mol} / \mathrm{l})$ were mixed, and then $0.5 \mathrm{ml}$ of PMS solution $(60 \mu \mathrm{mol} / \mathrm{l})$ was added to start the reaction. After being incubated at room temperature for $5 \mathrm{~min}$, the absorbance of the mixture was read at $560 \mathrm{~nm}\left(A_{s}\right)$, mixture without PEOR samples was used as blank control $\left(\mathrm{A}_{0}\right)$. VC at concentrations of 0.01 , $0.02,0.03,0.04$, and $0.05 \mathrm{mg} / \mathrm{ml}$ was used as positive control. The superoxide anion radical-scavenging rate was estimated by the following equation:

$$
\begin{aligned}
& \text { Superoxide anion }- \text { scavenging rate }(\%) \\
& =\left(A_{0}-A_{s}\right) \times \frac{100}{A_{0}} .
\end{aligned}
$$

2.6.4. Reducing Power Assay. Reducing power was assayed according to the method reported by Wang et al. [34] with some modifications. Different concentrations $(8,10,12,14$, and $16 \mathrm{mg} / \mathrm{ml}$ ) of PEOR solutions were prepared. $1 \mathrm{ml}$ of PEOR solution, $2.5 \mathrm{ml}$ of phosphate buffer $(0.2 \mathrm{~mol} / \mathrm{l}$, $\mathrm{pH} 6.6)$, and $2.5 \mathrm{ml}$ of potassium ferricyanide solution ( $1 \%$, $w / v)$ were mixed and incubated at $50^{\circ} \mathrm{C}$ for $20 \mathrm{~min} ; 2.5 \mathrm{ml}$ of trichloroacetic acid $(10 \%, v / v)$ was added. The mixture was centrifuged at $3000 \mathrm{rpm}$ for $10 \mathrm{~min}, 2.5 \mathrm{ml}$ of supernatant was mixed with $2.5 \mathrm{ml}$ of distilled water and $0.5 \mathrm{ml}$ of ferric chloride solution $(0.1 \%, w / v)$, and then the absorbance at $700 \mathrm{~nm}$ was measured. $\mathrm{VC}$ at concentrations of $0.01,0.02$, $0.03,0.04$, and $0.05 \mathrm{mg} / \mathrm{ml}$ was used as positive control.

2.7. In Vivo Antioxidant Activity of PEOR. Sixty male ICR mice (aged 4 weeks, weighing $20 \pm 2 \mathrm{~g}$ ) were randomly divided into six groups (10 mice per group) as follows: normal control (NC), positive control (PC), oxidative stress model control (MC), and three PEOR-treated groups. Prior to experiment, animals were fasted for $12 \mathrm{~h}$. Mice in PEORtreated groups were administered with PEOR solution $(2 \mathrm{ml} / 100 \mathrm{~g} \mathrm{BW})$ by oral gavage once a day in doses of 100 , 200 , and $400 \mathrm{mg} / \mathrm{kg} \mathrm{BW}$ for 30 consecutive days, mice in $\mathrm{PC}$ group were treated with VC in a dose of $200 \mathrm{mg} / \mathrm{kg} \mathrm{BW}$, and mice in NC and MC groups were dosed with equal amount of distilled water. Dose selection of PEOR was based on the results of preliminary test (data not shown).

On the last day, after being fasted for $12 \mathrm{~h}$ (free access to water), except the mice in NC group, others were orally administered with a solution of $50 \%(v / v)$ ethanol to induce oxidative stress in a dose of $12 \mathrm{ml} / \mathrm{kg} \mathrm{BW}$. After $6 \mathrm{~h}$, animals were anesthetized with pentobarbital sodium, and blood samples were collected from orbit to prepare serum for the determination of T-SOD and MDA by being centrifuged at $4^{\circ} \mathrm{C}, 4000 \mathrm{rpm}$ for $10 \mathrm{~min}$. Then animals were euthanized with carbon dioxide, livers were immediately dissected, washed, homogenized in physiological saline, and centrifuged at $4^{\circ} \mathrm{C}, 4000 \mathrm{rpm}$ for $10 \mathrm{~min}$ to obtain supernatant for the quantification of GSH and PCO. The MDA (thiobarbituric acid method), T-SOD (hydroxylamine method), GSH (spectrophotometric method), and PCO (spectrophotometric method) levels were determined according to the methods described in the instructions of kits (Jiancheng Biotechnology Co. Ltd, Nanjing, Jiangsu, China) [41, 42].

2.8. In Vivo Antifatigue Activity of PEOR. The in vivo antifatigue evaluation of PEOR was designed and performed according to our previous work and reported method [13, $43,44]$ with some modifications.

2.8.1. Experimental Design. Before experiment, male ICR mice (aged 4 weeks, weighing $20 \pm 2 \mathrm{~g}$ ) swam twice a day (10 min each time) within one week to accustom themselves to swimming; mice that failed to learn swimming were eliminated. Then 90 animals were randomly divided into three groups (30 animals each) as normal control (NC), positive control (PC), and PEOR-treated group. After being fasted for $12 \mathrm{~h}$, mice in NC group were orally administered with distilled water, mice in PC group were treated with ginsenoside $(2.5 \mathrm{mg} \mathrm{Rg} 3$ per $100 \mathrm{mg}$ ) in a dose of $50 \mathrm{mg} / \mathrm{kg} \mathrm{BW}$, and mice in PEOR-treated group were administered with PEOR in a dose of $400 \mathrm{mg} / \mathrm{kg}$ BW once a day for 30 consecutive days. Then the animals in each group were further divided into three subgroups of 10 mice each according to following three test/determination section (Figure 1).

2.8.2. Exhaustive Swimming Test. On the last day, animals were allowed to rest for $30 \mathrm{~min}$ after oral gavage, and ten mice in each group were attached to the tail of a tin wire (about $5 \%$ of body weight). Then mice were placed in a plastic swimming pool $(50 \mathrm{~cm} \times 50 \mathrm{~cm} \times 40 \mathrm{~cm})$ with temperature of $25 \pm 1^{\circ} \mathrm{C}$ and depth of $30 \mathrm{~cm}$. Exhaustive swimming time was recorded as the time when animals failed to rise to the surface to breathe within $10 \mathrm{~s}$.

2.8.3. Determination of BUN and HG. After the last administration, mice in the second subgroup were allowed to rest for $30 \mathrm{~min}$ then forced to swim without load. After swimming for $30 \mathrm{~min}$, animals were anesthetized with pentobarbital sodium, and blood samples were collected from orbit to prepare serum for the quantification of BUN using kit (urease-Berthelot method, Jiancheng Biotechnology Co. Ltd, Nanjing, Jiangsu, China). Then mice were euthanized with carbon dioxide, and livers were harvested and homogenized for the determination of HG using kit (spectrophotometric method, Jiancheng Biotechnology Co. Ltd, Nanjing, Jiangsu, China). 


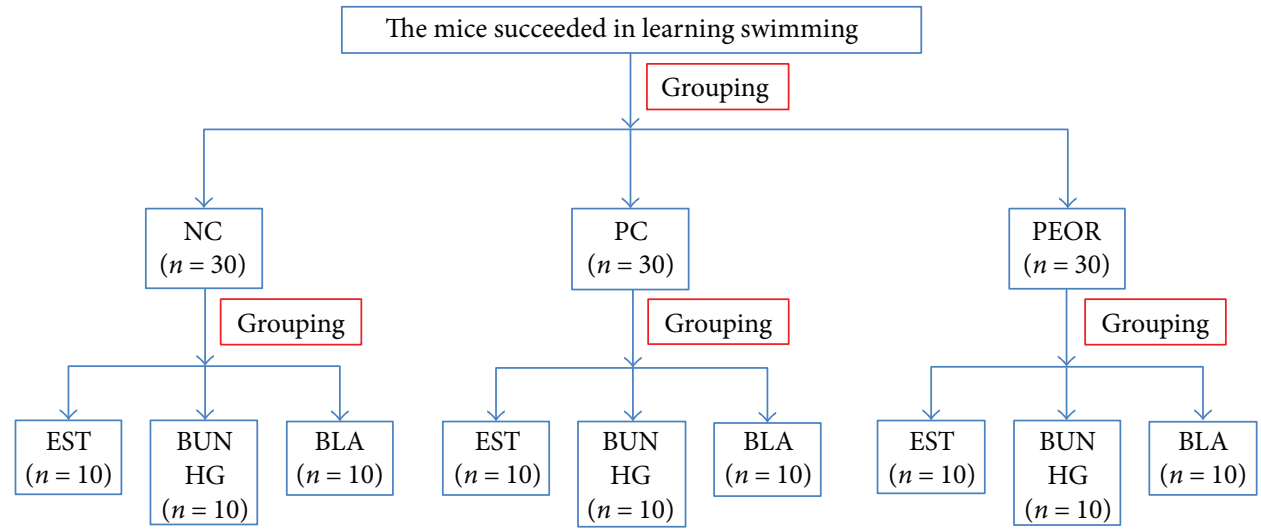

FIGURE 1: The flow chart for experimental design of antifatigue evaluation of PEOR. NC: normal control (distilled water); PC: positive control (ginsenoside, $50 \mathrm{mg} / \mathrm{kg} \mathrm{BW);} \mathrm{PEOR} \mathrm{(400} \mathrm{mg/kg} \mathrm{BW);} \mathrm{EST:} \mathrm{exhaustive} \mathrm{swimming} \mathrm{test;} \mathrm{BUN:} \mathrm{blood} \mathrm{urea} \mathrm{nitrogen;} \mathrm{HG:} \mathrm{hepatic} \mathrm{glycogen;} \mathrm{BLA:}$ blood lactic acid.

2.8.4. Determination of BLA. Mice in the third subgroup were also subjected to a forced swimming without load, before swimming, blood samples were taken from the eyeball for the quantification of BLA $\left(\mathrm{C}_{1}\right)$ using a Lactate Scout+ analyzer (EKF Diagnostics, Cardiff, WAL, England). After swimming for $30 \mathrm{~min}$, another blood samples were immediately collected for the determination of BLA $\left(\mathrm{C}_{2}\right)$, and after resting for $20 \mathrm{~min}$, blood samples were taken again for the determination of BLA $\left(\mathrm{C}_{3}\right)$. The area under the curve of $\mathrm{BLA}\left(\mathrm{AUC}_{\mathrm{BLA}}\right)$ was calculated as the following formula:

$$
\mathrm{AUC}_{\mathrm{BLA}}\left(\frac{\mathrm{mmol}}{\mathrm{l}}\right)=5 \times\left(\mathrm{C}_{1}+3 \times \mathrm{C}_{2}+2 \times \mathrm{C}_{3}\right)
$$

2.9. Statistical Analysis. Experimental data was expressed as mean \pm SD (standard deviation), and statistical analysis was performed using a SPSS19.0 software (SPSS Inc., Chicago, USA). For results of the in vitro evaluation, $t$-test was used to evaluate the significance of distances between two means, and for results of the in vivo evaluation, Levene's test was used to detect the homogeneity of variances, if homogeneous, one-way analysis of variance (ANOVA) was operated.

\section{Results}

3.1. General Chemical Analysis. The total protein content of PEOR was found to be $80.35 \pm 2.71 \%$. In addition, PEOR contains $2.64 \pm 0.15 \%$ lipids, $7.41 \pm 0.28 \%$ ash, and 1.12 $\pm 0.06 \%$ moisture.

3.2. Amino Acid Analysis of PEOR. The chromatograms of amino acid standard mixture and PEOR sample were shown in Figure 2, and amino acid composition of PEOR was summarized in Table 1 . Seventeen amino acids were noted in PEOR, seven of them were essential amino acids, which accounted for $41.9 \%$. The top three amino acids present in PEOR were threonine, aspartic acid, and serine with threonine as the highest content of $120 \mathrm{mg} / \mathrm{g}$.
3.3. Acute Toxicity of PEOR. During the period of 14 days, no death and noticeable clinical signs associated with toxicity were found in NC and all PEOR-treated groups.

3.3.1. Body Weight. As shown in Table 2, the body weights of mice increased gradually during the study period, when compared with NC group, no significant differences in body weight changes were observed.

3.3.2. Relative Organ Weight. The effects of PEOR on relative weight of vital organs including liver, kidney, spleen, and testis/ovary were demonstrated in Table 3 . No significant differences in relative organ weight were noted between $\mathrm{NC}$ and PEOR-treated groups.

3.3.3. Biochemical Parameter. Some biochemical parameters (AST, ALT, GLU, TG, CRE, and BUN) reflecting the pathological changes of vital organs were determined, and results were shown in Table 4. Statistical analysis of these parameters indicated that there were no significant differences between NC and PEOR-treated groups.

3.3.4. Histopathological Examination. The microphotographs of histopathological observation of liver, spleen, and kidney in NC and PEOR-treated groups were exhibited in Figure 3. When compared with NC group, any obvious tissue changes were not found.

3.4. In Vitro Antioxidant Activity of PEOR. The in vitro scavenging capacities of PEOR against hydroxyl, DPPH, and superoxide anion radicals, as well as ferric ion-reducing power, were shown in Figure 4, and the corresponding half inhibitory concentration $\left(\mathrm{IC}_{50}\right)$ value was expressed in Table 5. In the range of $2 \sim 10 \mathrm{mg} / \mathrm{ml}$, hydroxyl radicalscavenging activity of PEOR increased with the increase of sample concentration, the highest scavenging rate against hydroxyl radical of PEOR was $86.35 \pm 1.82 \%$, and the $\mathrm{IC}_{50}$ value was $4.85 \pm 0.06 \mathrm{mg} / \mathrm{ml}$, which was much lower than that of positive control ( $\mathrm{VC}$ ) with the $\mathrm{IC}_{50}$ value of 0.0476 $\pm 0.0005 \mathrm{mg} / \mathrm{ml}$ (Figure $4(\mathrm{a})$ ). As for DPPH radical, in the range of $2 \sim 10 \mathrm{mg} / \mathrm{ml}$, PEOR also displayed radical- 


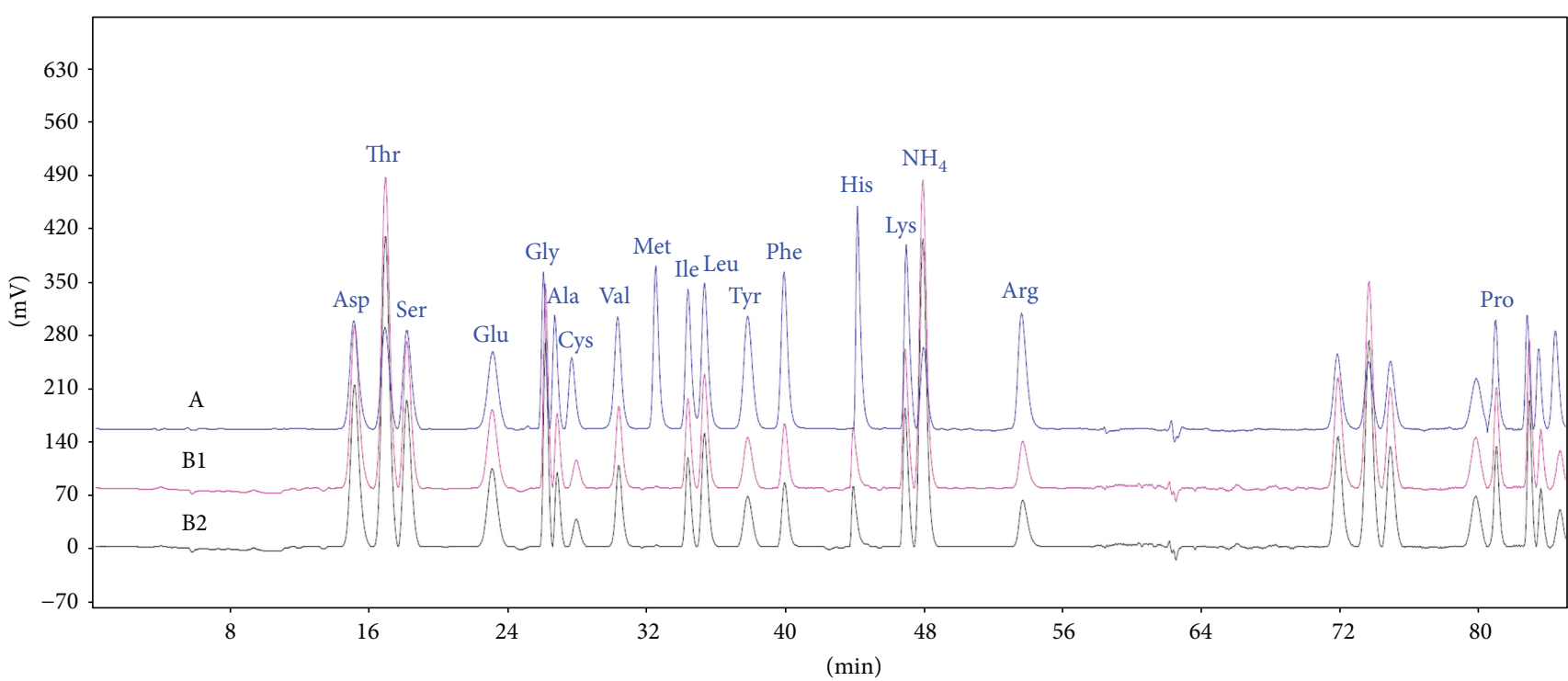

FIGURE 2: Chromatograms of amino acid standard mixture (A) and PEOR sample (B1 and B2). Asp: aspartic acid; Thr: threonine; Ser: serine; Glu: glutamic acid; Gly: glycine; Ala: alanine; Cys: cystine; Val: valine; Met: methionine; Ile: isoleucine; Leu: leucine; Tyr: tyrosine; Phe: phenylalanine; His: histidine; Lys: lysine; Arg: arginine; Pro: proline. Two parallel injections of sample.

TABle 1: Amino acid composition of PEOR.

\begin{tabular}{lcc}
\hline Amino acid & Content $(\mathrm{mg} / \mathrm{g})$ & Percent composition (\%) \\
\hline Aspartic acid & 69.4 & 10.4 \\
a Threonine & 120 & 18.0 \\
Serine & 53.3 & 7.98 \\
Glutamic acid & 51.8 & 7.75 \\
Glycine & 44.3 & 6.63 \\
Alanine & 30.8 & 4.61 \\
Cystine & 37.5 & 5.61 \\
${ }^{\mathrm{a}}$ Valine & 28.5 & 4.27 \\
${ }^{\mathrm{a}}$ Methionine & 1.13 & 0.17 \\
${ }^{\mathrm{a}}$ Isoleucine & 28.1 & 4.21 \\
${ }^{\mathrm{a}}$ Leucine & 36.4 & 5.45 \\
Tyrosine & 25.1 & 3.76 \\
${ }^{\mathrm{a}}$ Phenylalanine & 23.6 & 3.53 \\
Histidine & 13.9 & 2.08 \\
${ }^{a}$ Lysine & 42.0 & 6.29 \\
Arginine & 25.5 & 3.82 \\
Proline & 37.1 & 5.55 \\
Total & 668 & 100 \\
\hline
\end{tabular}

${ }^{a}$ Essential amino acid.

scavenging activity, which increased with the elevation of PEOR concentration, and the highest scavenging rate was $65.23 \pm 1.22 \%$, but inferior to $\mathrm{VC}$, the $\mathrm{IC}_{50}$ values of PEOR and VC against DPPH radical were $4.98 \pm 0.37 \mathrm{mg} / \mathrm{ml}$ and $0.036 \pm 0.0011 \mathrm{mg} / \mathrm{ml}$, respectively (Figure 4(b)). In the range of $1 \sim 5 \mathrm{mg} / \mathrm{ml}$, PEOR exhibited scavenging activity against superoxide anion radical in a good linear relationship to sample concentration $\left(R^{2}=0.9971\right)$, and the highest scavenging rate was $89.6 \pm 2.43 \%$, but its activity was still
TABLE 2: Effects of PEOR on body weight in mice.

\begin{tabular}{lcccc}
\hline Sex & Group & $\begin{array}{c}\text { Initial weight } \\
(\mathrm{g})\end{array}$ & $\begin{array}{c}\text { Final weight } \\
(\mathrm{g})\end{array}$ & $\begin{array}{c}\text { Weight gain } \\
(\mathrm{g})\end{array}$ \\
\hline \multirow{4}{*}{ Male } & $\mathrm{NC}$ & $19.0 \pm 1.02$ & $31.3 \pm 2.27$ & $12.3 \pm 2.13$ \\
& $5 \mathrm{~g} / \mathrm{kg}$ & $19.4 \pm 1.29$ & $30.8 \pm 2.07$ & $11.4 \pm 1.78$ \\
& $10 \mathrm{~g} / \mathrm{kg}$ & $19.1 \pm 0.91$ & $30.9 \pm 1.93$ & $11.8 \pm 1.51$ \\
& $20 \mathrm{~g} / \mathrm{kg}$ & $19.6 \pm 1.42$ & $31.1 \pm 2.38$ & $11.5 \pm 1.87$ \\
& $\mathrm{NC}$ & $18.2 \pm 0.72$ & $28.7 \pm 1.87$ & $10.5 \pm 1.33$ \\
Female & $5 \mathrm{~g} / \mathrm{kg}$ & $18.7 \pm 0.94$ & $28.4 \pm 1.39$ & $9.71 \pm 0.78$ \\
& $10 \mathrm{~g} / \mathrm{kg}$ & $19.1 \pm 0.62$ & $28.8 \pm 2.12$ & $9.65 \pm 1.49$ \\
& $20 \mathrm{~g} / \mathrm{kg}$ & $18.5 \pm 0.79$ & $29.2 \pm 1.83$ & $10.7 \pm 1.24$ \\
\hline
\end{tabular}

No statistically significant differences were noted; NC: normal control; values are the means $\pm \mathrm{SD}(n=10)$.

much lower than $\mathrm{VC}$; the corresponding $\mathrm{IC}_{50}$ values were $2.58 \pm 0.02 \mathrm{mg} / \mathrm{ml}$ and $0.0332 \pm 0.0006 \mathrm{mg} / \mathrm{ml}$, respectively (Figure $4(\mathrm{c})$ ). In the range of $8 \sim 16 \mathrm{mg} / \mathrm{ml}$, the absorbance (A) of PEOR at $700 \mathrm{~nm}$ increased with the increase of sample concentration. When $A_{700 \mathrm{~nm}}$ was 0.2 , the concentration of PEOR was $11.8 \pm 0.02 \mathrm{mg} / \mathrm{ml}$, and the corresponding concentration of VC was $0.0395 \pm 0.0002 \mathrm{mg} / \mathrm{ml}$ (Figure 4(d)).

\subsection{In Vivo Antioxidant Activity of PEOR}

3.5.1. Effects of PEOR on MDA. As shown in Figure 5(a), MDA contents decreased with the increase of PEOR dose; the lowest content of MDA was $5.28 \pm 1.27 \mathrm{mmol} / \mathrm{l}$, 2.6-fold lower than that in MC, and 1.8-fold lower than that in PC group. Statistical analysis of MDA contents indicated that there were significant differences $(P<0.01)$ between NC and $\mathrm{MC}$ groups. When compared with $\mathrm{MC}$ group, significant differences $(P<0.01)$ were found in PC and all PEOR-treated 
TABLE 3: Effects of PEOR on relative organ weight in mice.

\begin{tabular}{lccccc}
\hline Sex & Group & $\begin{array}{c}\text { Liver } \\
(\%)\end{array}$ & $\begin{array}{c}\text { Kidney } \\
(\%)\end{array}$ & $\begin{array}{c}\text { Spleen } \\
(\%)\end{array}$ & $\begin{array}{c}\text { Testis/ovary } \\
(\%)\end{array}$ \\
\hline \multirow{3}{*}{ Male } & $\mathrm{NC}$ & $4.26 \pm 0.49$ & $1.33 \pm 0.23$ & $0.27 \pm 0.05$ & $0.51 \pm 0.09$ \\
& $5 \mathrm{~g} / \mathrm{kg}$ & $4.35 \pm 0.53$ & $1.29 \pm 0.17$ & $0.26 \pm 0.07$ & $0.52 \pm 0.08$ \\
& $10 \mathrm{~g} / \mathrm{kg}$ & $4.22 \pm 0.57$ & $1.31 \pm 0.28$ & $0.26 \pm 0.05$ & $0.5 \pm \pm 0.07$ \\
& $20 \mathrm{~g} / \mathrm{kg}$ & $4.43 \pm 0.54$ & $1.30 \pm 0.19$ & $0.28 \pm 0.04$ & $0.04 \pm 0.04$ \\
Female & $\mathrm{NC}$ & $4.13 \pm 0.38$ & $1.17 \pm 0.18$ & $0.19 \pm 0.05$ & $0.042 \pm 0.008$ \\
& $5 \mathrm{~g} / \mathrm{kg}$ & $4.18 \pm 0.42$ & $1.15 \pm 0.16$ & $0.20 \pm 0.06$ & $0.03 \pm 0.006$ \\
& $10 \mathrm{~g} / \mathrm{kg}$ & $4.16 \pm 0.37$ & $1.16 \pm 0.19$ & $0.21 \pm 0.06$ & $0.041 \pm 0.007$ \\
\hline
\end{tabular}

No statistically significant differences were noted; NC: normal control; values are the means \pm SD $(n=10)$.

TABLE 4: Effects of PEOR on biochemical parameter in mice.

\begin{tabular}{|c|c|c|c|c|c|c|c|}
\hline Sex & Group & $\begin{array}{l}\text { AST } \\
(\mathrm{U} / \mathrm{l})\end{array}$ & $\begin{array}{l}\text { ALT } \\
(\mathrm{U} / \mathrm{l})\end{array}$ & $\begin{array}{c}\text { GLU } \\
(\mathrm{mmol} / \mathrm{l})\end{array}$ & $\begin{array}{c}\mathrm{TG} \\
(\mathrm{mmol} / \mathrm{l})\end{array}$ & $\begin{array}{c}\mathrm{CRE} \\
(\mu \mathrm{mol} / \mathrm{l})\end{array}$ & $\begin{array}{c}\text { BUN } \\
(\mathrm{mmol} / \mathrm{l})\end{array}$ \\
\hline \multirow{4}{*}{ Male } & $\mathrm{NC}$ & $143 \pm 12.1$ & $31.9 \pm 4.08$ & $4.53 \pm 0.58$ & $2.13 \pm 0.08$ & $45.2 \pm 6.13$ & $7.18 \pm 0.55$ \\
\hline & $5 \mathrm{~g} / \mathrm{kg}$ & $142 \pm 11.6$ & $33.0 \pm 3.34$ & $4.41 \pm 0.51$ & $2.04 \pm 0.17$ & $47.6 \pm 7.47$ & $6.79 \pm 0.46$ \\
\hline & $10 \mathrm{~g} / \mathrm{kg}$ & $141 \pm 12.3$ & $32.7 \pm 3.93$ & $4.49 \pm 0.53$ & $2.05 \pm 0.09$ & $43.9 \pm 6.08$ & $7.06 \pm 0.68$ \\
\hline & $20 \mathrm{~g} / \mathrm{kg}$ & $142 \pm 11.2$ & $32.3 \pm 4.22$ & $4.51 \pm 0.64$ & $2.03 \pm 0.07$ & $45.8 \pm 5.66$ & $7.36 \pm 0.71$ \\
\hline \multirow{4}{*}{ Female } & $\mathrm{NC}$ & $118 \pm 10.7$ & $26.9 \pm 3.52$ & $4.38 \pm 0.69$ & $1.84 \pm 0.12$ & $39.6 \pm 5.73$ & $7.73 \pm 0.91$ \\
\hline & $5 \mathrm{~g} / \mathrm{kg}$ & $117 \pm 9.14$ & $28.1 \pm 3.83$ & $4.75 \pm 0.53$ & $1.87 \pm 0.28$ & $37.2 \pm 5.48$ & $8.06 \pm 0.54$ \\
\hline & $10 \mathrm{~g} / \mathrm{kg}$ & $121 \pm 8.76$ & $27.1 \pm 2.89$ & $4.63 \pm 0.62$ & $2.06 \pm 0.15$ & $36.8 \pm 7.61$ & $7.94 \pm 0.62$ \\
\hline & $20 \mathrm{~g} / \mathrm{kg}$ & $118 \pm 10.2$ & $27.7 \pm 3.23$ & $5.06 \pm 0.68$ & $1.83 \pm 0.26$ & $38.4 \pm 6.33$ & $8.15 \pm 1.23$ \\
\hline
\end{tabular}

No statistically significant differences were noted; NC: normal control; values are the means \pm SD $(n=10)$.

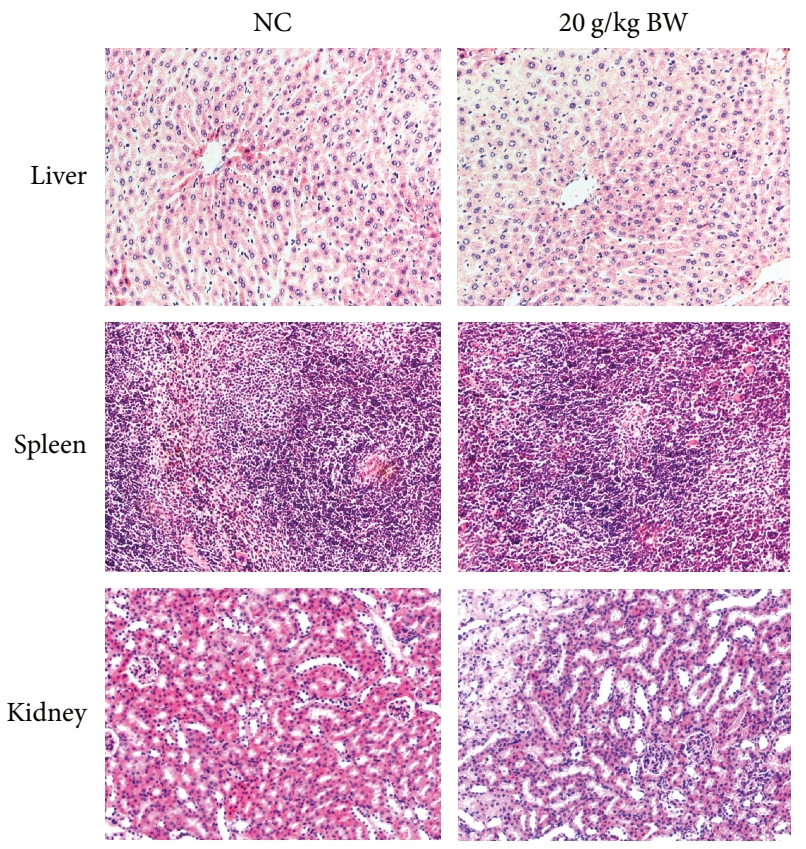

FIGURE 3: Representative microphotographs of the liver, spleen, and kidney of mice at $200 \times$ from NC and $20 \mathrm{~g} / \mathrm{kg}$ BW of PEORtreated groups. groups. Significant differences $(P<0.01)$ were also noted compared with PC group.

3.5.2. Effects of PEOR on GSH. As shown in Figure 5(b), when compared with NC, significant differences $(P<0.01)$ in GSH contents were observed in MC group, and significant differences $(P<0.01)$ were also found between $\mathrm{MC}$ and other groups. GSH contents increased with the increase of dose; when PEOR dose was $400 \mathrm{mg} / \mathrm{kg}$, the content of $\mathrm{GSH}$ reached $17.85 \pm 3.82 \mathrm{mg} / \mathrm{gprot}$, which was a little higher than that in PC (16.36 $\pm 3.82 \mathrm{mg} / \mathrm{gprot})$, but no statistically significant differences were noted.

3.5.3. Effects of PEOR on T-SOD. As shown in Figure 5(c), TSOD activities in $\mathrm{MC}$ decreased significantly $(P<0.01)$ compared with NC. When compared with MC, significant differences $(P<0.01)$ in T-SOD were found in PC and all PEOR-treated groups. Oral administration of PEOR can increase T-SOD activities in a dose-dependent manner $(P<0.01)$, when PEOR dose reached $400 \mathrm{mg} / \mathrm{kg}$, the $\mathrm{T}$ SOD activity was $234.6 \pm 14.5 \mathrm{U} / \mathrm{ml}$, which was significantly $(P<0.01)$ higher than that in $\mathrm{PC}(179.6 \pm 21.0 \mathrm{U} / \mathrm{ml})$.

3.5.4. Effects of PEOR on PCO. As shown in Figure 5(d), PCO contents in MC group were significantly higher $(P<0.01)$ than those in NC. When compared with MC, significant differences $(P<0.01)$ in PCO were found in PC and all 


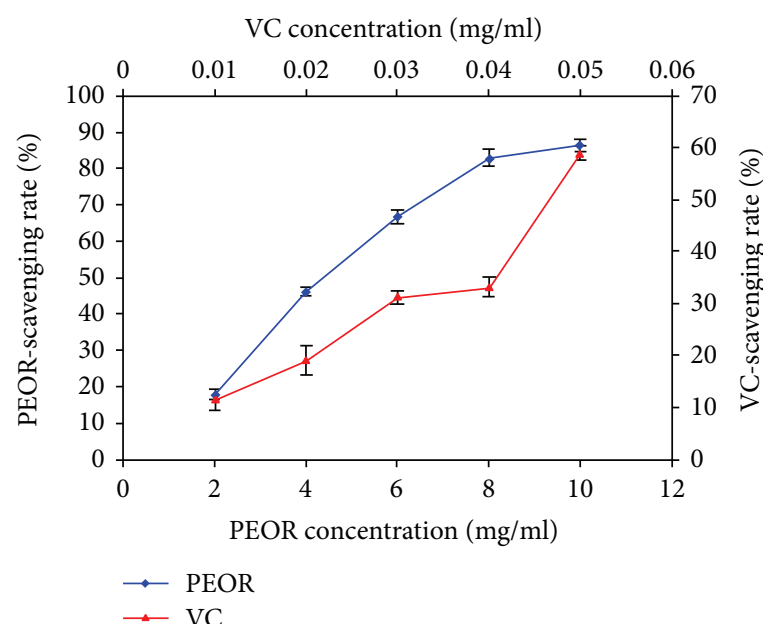

(a)

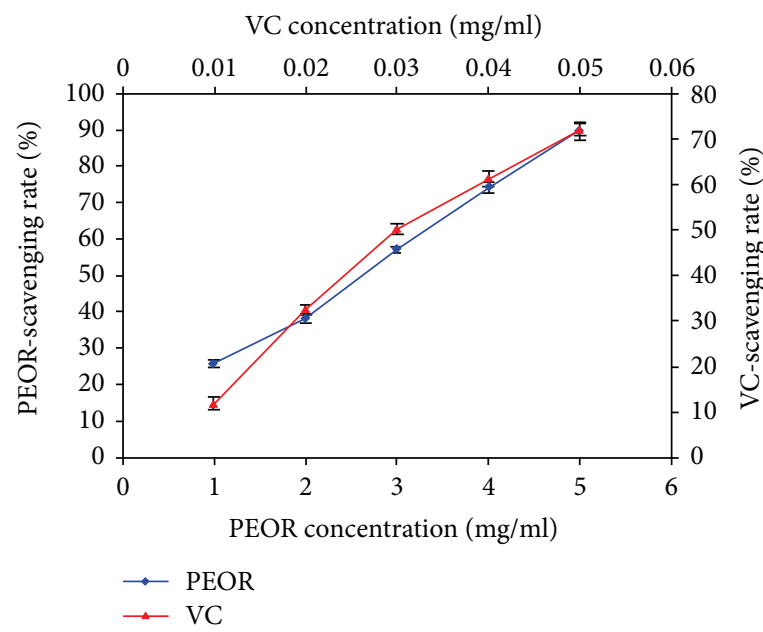

(c)

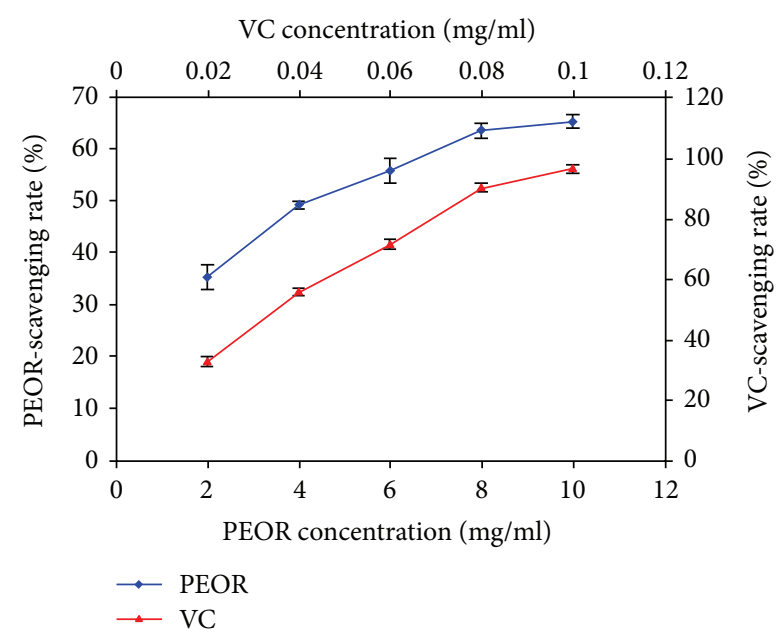

(b)

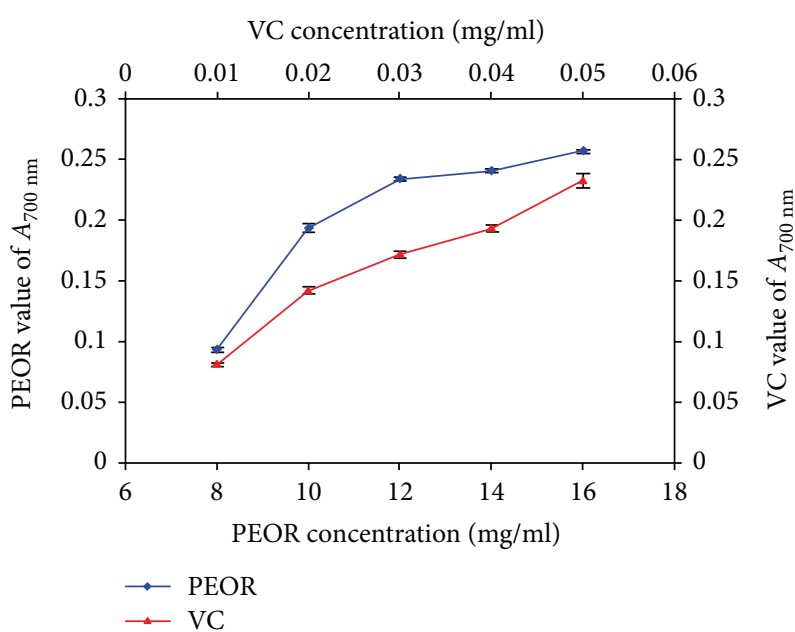

(d)

FIgURE 4: The in vitro antioxidant activities of PEOR using VC as a positive control. (a) Hydroxyl radical-scavenging activity; (b) DPPH radical-scavenging activity; (c) superoxide anion radical-scavenging activity; (d) reducing power. Data was expressed as the mean $\pm \mathrm{SD}(n=3)$.

TABLE 5: The $\mathrm{IC}_{50}$ values and reducing power of PEOR and VC.

\begin{tabular}{lcccc}
\hline Sample & Hydroxyl radical & $\mathrm{IC}_{50}(\mathrm{mg} / \mathrm{ml})$ & Superoxide anion & ${\text { Reducing power }(\mathrm{mg} / \mathrm{ml})^{\mathrm{a}}}^{*}$ \\
\hline PEOR & $4.85 \pm 0.06^{* *}$ & $4.98 \pm 0.37^{* *}$ & $2.58 \pm 0.02^{* *}$ & $11.8 \pm 0.02^{* *}$ \\
VC & $0.0476 \pm 0.0005$ & $0.036 \pm 0.0011$ & $0.0332 \pm 0.0006$ & $0.0395 \pm 0.0002$ \\
\hline
\end{tabular}

${ }^{a}$ The corresponding concentrations of PEOR and VC, when $A_{700 \mathrm{~nm}}=0.2$; data was expressed as the mean $\pm \mathrm{SD}(n=3)$; symbol indicates statistically significant differences, ${ }^{* *} P<0.01$ versus VC group.

PEOR-treated groups. PCO contents decreased in a dosedependent manner $(P<0.01)$, and significant differences $(P<0.01)$ were noted in $400 \mathrm{mg} / \mathrm{kg}$ of $P E O R$-treated group compared with PC $(1.16 \pm 0.37 \mathrm{nmol} / \mathrm{mgprot}$ versus $2.62 \pm 0.99 \mathrm{nmol} / \mathrm{mgprot})$.

\subsection{In Vivo Antifatigue Activity of PEOR}

3.6.1. Exhaustive Swimming Test. As shown in Figure 6, there were significant differences $(P<0.01)$ between NC and PEOR-treated groups, and the swimming time was $6.38 \pm 2.26 \mathrm{~min}, 1.9$-fold longer than that in NC. When compared with PC, significant differences $(P<0.05)$ were found in PEOR-treated group, approximately 1.5 -fold longer than that in PC.

3.6.2. Effects of PEOR on BUN. As shown in Figure 7, when compared with NC, BUN contents in PC and PEORtreated groups were significantly $(P<0.05)$ lower by $18 \%$ and $17 \%$, respectively. 


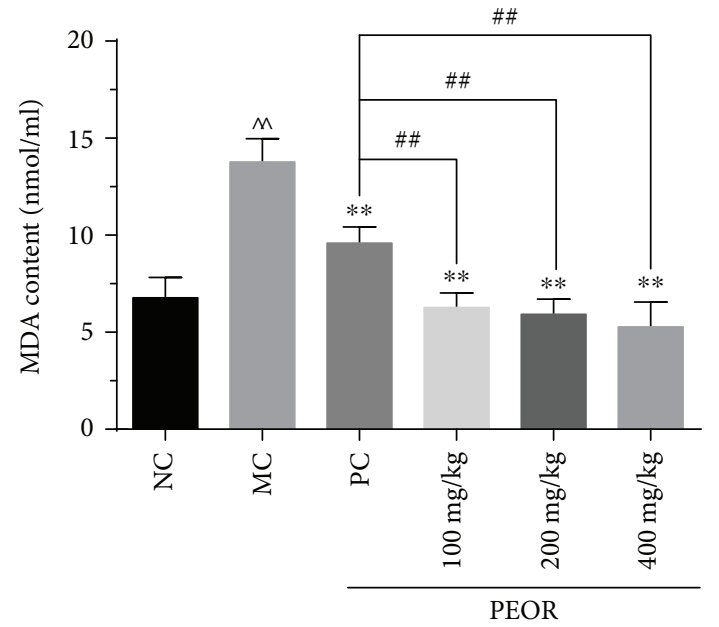

(a)

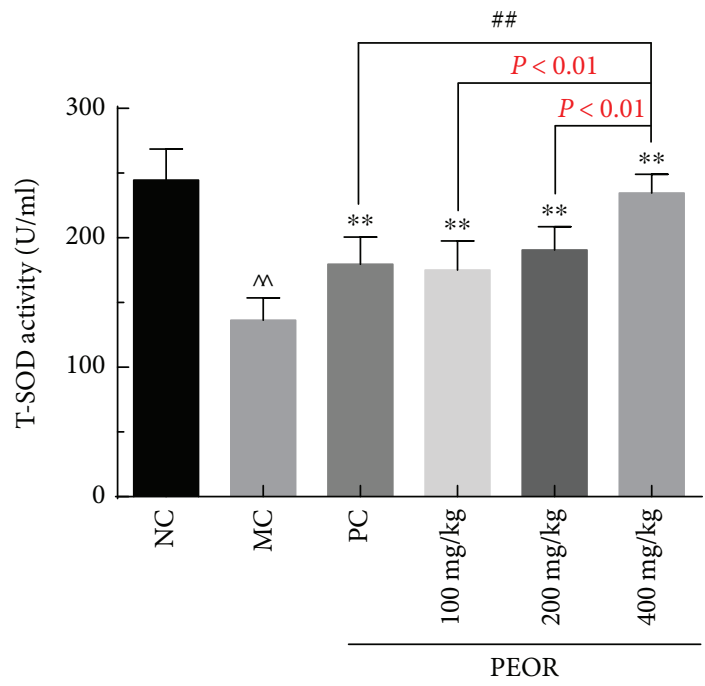

(c)

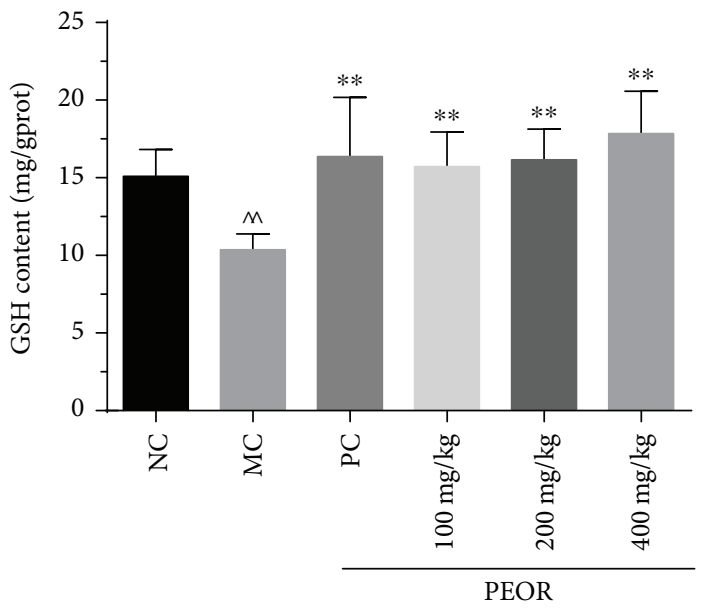

(b)

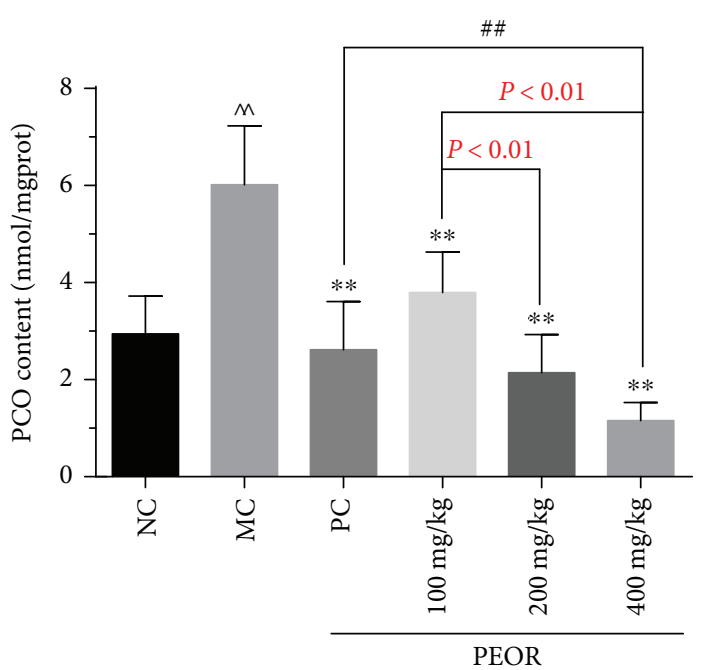

(d)

Figure 5: Effects of PEOR on (a) MDA, (b) GSH, (c) T-SOD, and (d) PCO. Data denoted were means + SD ( $n=10)$. Different symbols indicate statistically significant differences, ${ }^{\wedge} P<0.01$ as compared with $\mathrm{NC}$ group; ${ }^{* *} P<0.01$ as compared with $\mathrm{MC}$ group; $\#$ \# $P<0.01$ as compared with PC group. MDA: malonaldehyde; GSH: glutathione; T-SOD: total superoxide dismutase; PCO: protein carbonyls; NC: normal control; MC: model control; PC: positive control (VC in a dose of $200 \mathrm{mg} / \mathrm{kg} \mathrm{BW}$ ).

3.6.3. Effects of PEOR on HG. As shown in Figure 8, HG contents in PEOR-treated group was $37.66 \pm 11.49 \mathrm{mg} / \mathrm{g}$ and that in NC was $35.83 \pm 11.49 \mathrm{mg} / \mathrm{g}$; no significant differences were found. There were statistically significant differences $(P<0.01)$ in HG between PC and NC groups, the HG content in PC was $56.88 \pm 13.3 \mathrm{mg} / \mathrm{g}, 1.59$-fold higher than that in NC and 1.51-fold higher than that in PEORtreated group.

3.6.4. Effects of PEOR on BLA. BLA content at different time points ( $t_{\text {before swimming }}, t_{0 \text { min after swimming, }}$ and $t_{20 \mathrm{~min}}$ after swimming) was determined. As shown in Table 6, before swimming, no significant differences in BLA were noted among groups. When compared with $\mathrm{NC}$ group, at $0 \mathrm{~min}$ after swimming, the BLA contents in PC $(P<0.01)$ and PEOR-treated groups $(P<0.01)$ significantly decreased. After resting for $20 \mathrm{~min}$, the elevated BLA levels of all groups were reduced, and no statistically significant differences were observed. The $\mathrm{AUC}_{\mathrm{BLA}}$ value was calculated and found that there were significant differences $(P<0.05)$ in PC and PEOR-treated groups compared with NC group. The $\mathrm{AUC}_{\mathrm{BLA}}$ value in PEOR-treated group was similar to that in PC group $(115.4 \pm 24.7 \mathrm{mmol} / \mathrm{l}$ versus $114.4 \pm 19.4 \mathrm{mmol} / \mathrm{l})$.

\section{Discussion}

Since Oviductus ranae (OR) is a precious TCM with abundant protein contents, thus, in this paper, the protein-rich extract of OR (PEOR) was prepared and analyzed. The results indicated that PEOR contains $80.35 \pm 2.71 \%$ protein, which comprises seventeen amino acids, seven of them are essential amino acids with total contents of $41.9 \%$ (Figure 2 and Table 1). 


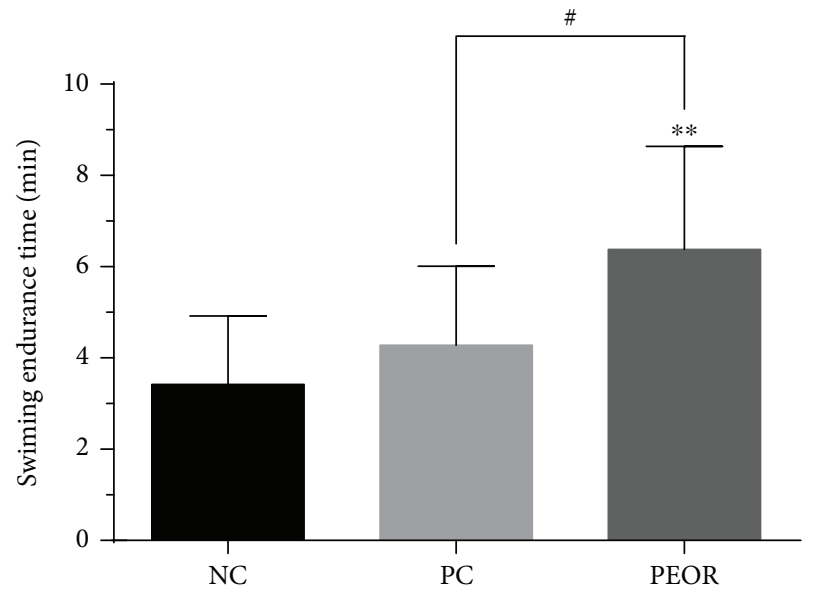

FIGURE 6: Effects of PEOR on exhaustive swimming endurance time. Data denoted were means + SD $(n=10)$. Different symbols indicate statistically significant differences, ${ }^{* *} P<0.01$ as compared with NC; ${ }^{\#} P<0.05$ as compared with PC. NC: normal control; PC: positive control (ginsenoside in a dose of $50 \mathrm{mg} / \mathrm{kg} \mathrm{BW}$ ); PEOR (400 mg/kg BW).

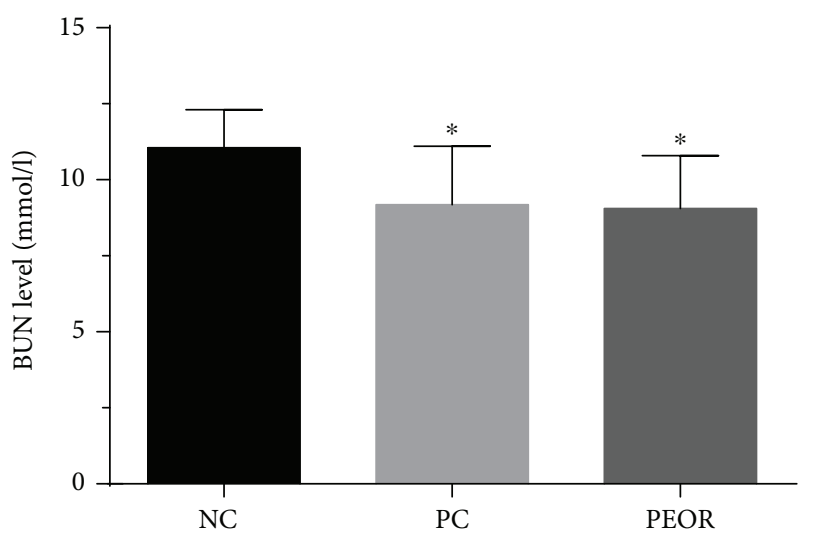

FIgURE 7: Effects of PEOR on BUN. Data denoted were means + SD $(n=10)$. Symbol indicates statistically significant differences, ${ }^{*} P<0.05$ as compared with NC group. BUN: blood urea nitrogen; NC: normal control; PC: positive control (ginsenoside in a dose of $50 \mathrm{mg} / \mathrm{kg} \mathrm{BW}$ ); PEOR (400 mg/kg BW).

In view of increasing number of therapeutic risks caused by the use of natural products [45-47] and our previous work [21], where we found that OR possesses high-safety property, in present study, only a single-dose oral toxicity with an observation of 14-day interval was conducted to evaluate the safety of PEOR, and $20 \mathrm{~g} / \mathrm{kg}$ was taken as an upper limit dose. During the observation period, no death and noticeable clinical signs associated with toxicity were found in NC and PEOR-treated groups; there were also no significant changes in body weights (Table 2), suggesting that the maximum tolerated dose (MTD) of PEOR may be higher than $20 \mathrm{~g} / \mathrm{kg}$ in mice.

Then a complete necropsy and serum biochemical and histopathological examinations were performed to assess the harmful effects of PEOR on inner organs. During necropsy, any noticeable abnormalities were not noticed, and

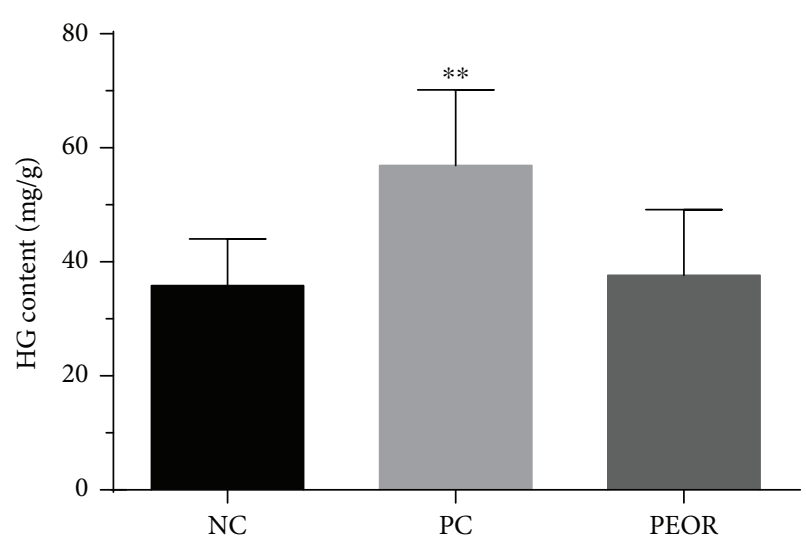

FIGURe 8: Effects of PEOR on HG. Data denoted were means + SD $(n=10)$. Symbol indicates statistically significant differences, ${ }^{* *} P<0.01$ as compared with NC group. HG: hepatic glycogen; NC: normal control; PC: positive control (ginsenoside in a dose of $50 \mathrm{mg} / \mathrm{kg}$ BW); PEOR (400 mg/kg BW).

TABLE 6: Effects of PEOR on BLA.

\begin{tabular}{lcccc}
\hline Group & $\begin{array}{c}\text { Before } \\
\text { swimming } \\
\left(\mathrm{C}_{1}\right) \\
(\mathrm{mmol} / \mathrm{l})\end{array}$ & $\begin{array}{c}0 \text { min after } \\
\text { swimming } \\
\left(\mathrm{C}_{2}\right) \\
(\mathrm{mmol} / \mathrm{l})\end{array}$ & $\begin{array}{c}20 \text { min after } \\
\text { swimming } \\
\left(\mathrm{C}_{3}\right) \\
(\mathrm{mmol} / \mathrm{l})\end{array}$ & $\begin{array}{c}\text { Area under the } \\
\text { curve } \\
(\mathrm{AUC} \mathrm{BLA}) \\
(\mathrm{mmol} / \mathrm{l})\end{array}$ \\
\hline NC & $2.88 \pm 0.79$ & $6.38 \pm 1.27$ & $3.28 \pm 0.67$ & $142.8 \pm 22.7$ \\
PC & $2.72 \pm 0.66$ & $4.63 \pm 0.94^{* *}$ & $3.13 \pm 0.61$ & $114.4 \pm 19.4^{*}$ \\
PEOR & $2.84 \pm 0.84$ & $4.59 \pm 1.04^{* *}$ & $3.24 \pm 1.17$ & $115.4 \pm 24.7^{*}$ \\
\hline
\end{tabular}

Data denoted were means \pm SD $(n=10)$. Different symbols indicate statistically significant differences, ${ }^{*} P<0.05$ and ${ }^{* *} P<0.01$ as compared with NC group. BLA: blood lactic acid; NC: normal control; PC: positive control (ginsenoside in a dose of $50 \mathrm{mg} / \mathrm{kg} \mathrm{BW})$; PEOR $(400 \mathrm{mg} / \mathrm{kg} \mathrm{BW})$. $\mathrm{AUC}_{\mathrm{BLA}}=5 \times\left(\mathrm{C}_{1}+3 \times \mathrm{C}_{2}+2 \times \mathrm{C}_{3}\right)$.

there were no significant differences in relative weights of vital organs including liver, kidney, spleen, and testis/ovary between NC and PEOR-treated groups (Table 3). Serum biochemical parameter is another important profile to detect the in vivo injury degree of organs, for example, ALT and AST are closely related to the function of the liver, while CRE and BUN are important biomarkers of renal toxicity [48, 49]. When compared with NC, no significant differences in AST, ALT, GLU, TG, BUN, and CRE were found in PEORtreated groups (Table 4), indicating that oral administration of PEOR has no harm on inner organs, which was further confirmed by the results of histopathological examination, where any obvious changes in liver, spleen, and kidney were not found compared with $\mathrm{NC}$ even in the maximum dose of $20 \mathrm{~g} / \mathrm{kg}$ (Figure 3).

In antioxidant assay, the in vitro evaluation was firstly conducted to obtain the antioxidant potential of PEOR. The results showed that PEOR exhibits certain scavenging capacities against hydroxyl, DPPH, and superoxide anion radicals, as well as certain reducing power to ferric ion in different concentrations, and activities increased with the increase of concentration (Figure 4 and Table 5). The free radicalscavenging activity of PEOR may be contributed by some of its amino acid residues, which may provide active hydrogen 


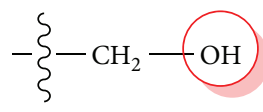

Serine

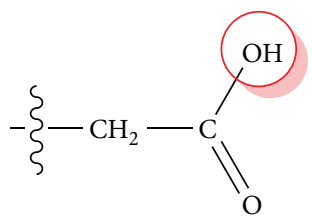

Aspartic acid

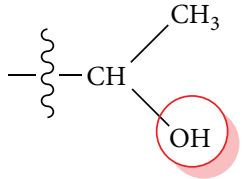

Threonine

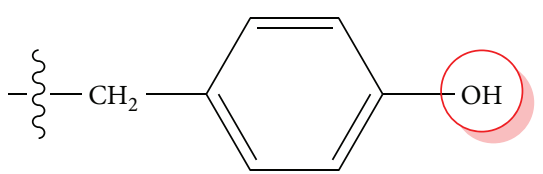

Tyrosine

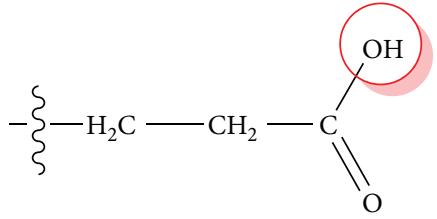

Glutamic acid

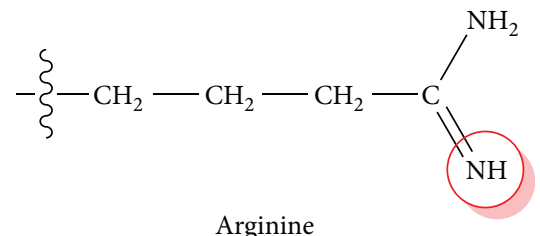

Arginine

FIGURE 9: Hydrogen-donor side chains of amino acids present in PEOR.

to destroy free radicals in liquid medium [50]; as shown in Table 1 and Figure 9 six amino acids with hydrogen-donor side chains were present in PEOR. However, when compared with VC, a well-known water-soluble antioxidant, the free radical-scavenging capacities and ferric ion-reducing power of PEOR were significantly $(P<0.01)$ lower; the $\mathrm{IC}_{50}$ values were about 100-fold higher than those of VC (Table 5). These disappointing results were consistent with the general finding that proteins or large polypeptides show lower free radicalscavenging capacities than their short peptides and amino acids, owing to the fact that smaller molecules are inclined to interact with free radicals more effectively [51]. In order to verify this hypothesis, the in vivo antioxidant evaluation of PEOR was further performed.

Based on the results of previous study [41], an ethanolinduced oxidative stress mice model was taken to evaluate the in vivo antioxidant activity of PEOR using VC in a dose of $200 \mathrm{mg} / \mathrm{kg}$ as positive control. Four antioxidant biomarkers including MDA (product of lipid peroxidation), GSH (endogenous antioxidant), T-SOD (antioxidase), and PCO (product of protein oxidation) were selected and determined. As shown in Figure 5, when compared with NC, significant differences $(P<0.01)$ in MDA, GSH, T-SOD, and $\mathrm{PCO}$ were found in MC, suggesting that an ethanolinduced oxidative stress mice model was well established. When compared with $\mathrm{MC}$, significant differences $(P<0.01)$ in MDA, GSH, T-SOD, and PCO were noted in PEORtreated groups, and the positive effects enhanced with the increase of dose; in the case of T-SOD and PCO, a dosedependent $(P<0.01)$ manner was observed. When compared with $\mathrm{PC}$, significant differences $(P<0.01)$ in MDA were found in all PEOR-treated groups, and similar tendencies $(P<0.01)$ in T-SOD and PCO were noted in $400 \mathrm{mg} / \mathrm{kg}$ of PEOR-treated group. These results revealed that oral administration of PEOR can reduce the oxidative stress caused by ethanol in mice and has more effects on MDA, T-SOD, and PCO than on GSH, especially for MDA. The $400 \mathrm{mg} / \mathrm{kg}$ in mice is a promising effective dose for antioxidant activity of PEOR. Its mechanism may involve the decrease of MDA and PCO formation and increase of
T-SOD activity and GSH synthesis. The strong in vivo antioxidant activity of PEOR contradicted with the weak activity of in vitro evaluation, which further confirmed our speculation, that is, the absorbed amino acids and small peptides may be the real forms of PEOR to exert antioxidant effects. Previous studies have manifested that the types and compositions of absorbed protein digestive products are closely related to their activities [34], and some amino acids including threonine, cysteine, methionine, tryptophan, tyrosine, histidine, phenylalanine, glutamic acid, aspartic acid, and lysine show good antioxidant activities both in vitro and in vivo [52-54]. As shown in Table 1, there were eight antioxidant amino acids present in PEOR, that is, aspartic acid $(69.4 \mathrm{mg} / \mathrm{g})$, threonine $(120 \mathrm{mg} / \mathrm{g})$, glutamic acid $(51.8 \mathrm{mg} / \mathrm{g})$, methionine $(1.13 \mathrm{mg} / \mathrm{g})$, tyrosine $(25.1 \mathrm{mg} / \mathrm{g})$, phenylalanine $(23.6 \mathrm{mg} / \mathrm{g})$, histidine $(13.9 \mathrm{mg} / \mathrm{g})$, and lysine $(42.0 \mathrm{mg} / \mathrm{g})$, which accounted for approximately $52 \%$ of the total amount of amino acids present in PEOR; their existence may play an important role in the exertion of antioxidant effect in vivo.

Several findings have manifested that intense exerciseinduced oxidative stress can cause the accumulation of free radicals and induce muscle fatigue $[55,56]$. Exogenous dietary antioxidants can potentiate the scavenging effects of endogenous antioxidants to fight against fatigue [11]. In consideration of the strong in vivo antioxidant effects of PEOR, as well as its high safety, we then evaluated the in vivo antifatigue activity of PEOR in the promising dose found in antioxidant evaluation $(400 \mathrm{mg} / \mathrm{kg})$. In our previous work [43], we noticed that ginsenoside in a dose of $35 \mathrm{mg} / \mathrm{kg}$ in mice is a good positive control for the evaluation of antifatigue effect of natural product; in order to ensure the control full effectiveness, we slightly raised the dose and selected $50 \mathrm{mg} / \mathrm{kg}$ as the dose of positive control. The exhaustive swimming time, coupled with some biochemical indicators (BUN, HG, and BLA) reflecting fatigue degree, was determined to estimate the in vivo antifatigue effect of PEOR. As shown in Figures 6-8, PEOR in a dose of $400 \mathrm{mg} / \mathrm{kg}$ can prolong the exhaustive swimming time and reduce the elevated BUN content caused by intense exercise in mice, but little 
effect on HG storage. As for BLA profile (Table 6), PEOR has little effect on BLA under resting-state conditions but significantly $(P<0.01)$ reduces the elevated BLA level induced by intense exercise. When compared with PC (ginsenoside, $50 \mathrm{mg} / \mathrm{kg}$ ), PEOR in a dose of $400 \mathrm{mg} / \mathrm{kg}$ can significantly $(P<0.05)$ improve the exercise tolerance, indicating that PEOR $(400 \mathrm{mg} / \mathrm{kg})$ is also a promising candidate for the development of nature-based antifatigue supplement, owing to the fact that exhaustive swimming time is the most direct and potent index to measure the antifatigue activity of tested sample [57]. The antifatigue capacity of PEOR could be also attributed to the extraenergy supplied by its glucogenic amino acids including aspartic acid $(69.4 \mathrm{mg} / \mathrm{g})$, threonine $(120 \mathrm{mg} / \mathrm{g})$, serine $(53.3 \mathrm{mg} / \mathrm{g})$, glutamic acid $(51.8 \mathrm{mg} / \mathrm{g})$, glycine $(44.3 \mathrm{mg} / \mathrm{g})$, alanine $(30.8 \mathrm{mg} / \mathrm{g})$, valine $(28.5 \mathrm{mg} / \mathrm{g})$, methionine $(1.13 \mathrm{mg} / \mathrm{g})$, isoleucine $(28.1 \mathrm{mg} / \mathrm{g})$, histidine $(13.9 \mathrm{mg} / \mathrm{g})$, arginine $(25.5 \mathrm{mg} / \mathrm{g})$, and proline $(37.1 \mathrm{mg} / \mathrm{g})$, which accounted for about $75 \%$ of the total amino acids present in PEOR (Table 1). The exact mechanism regarding antifatigue effect of PEOR deserved to be studied in the near future. In addition, due to the fact that most of the proteins enter the bloodstream as single amino acids $[58,59]$, in this paper, we mainly discussed the active contributions of amino acids in PEOR. Meanwhile, contributions of small peptides absorbed in intestinal tract to the antioxidant and antifatigue effects of PEOR, especially the chemical structures and activity-favourable conformations, need to be further explored.

\section{Conclusion}

In summary, PEOR is mainly composed of seventeen amino acids with seven essential ones. It possesses high safety with MTD value upper than $20 \mathrm{~g} / \mathrm{kg}$ in mice and exerts weak scavenging capacities against hydroxyl, DPPH, and superoxide anion radicals, as well as ferric ion-reducing power in vitro, but exhibits strong antioxidant activity in ethanol-induced oxidative stress mice model; its mechanism may involve the decrease of MDA and PCO formation, associated with the increase of T-SOD activity and GSH synthesis. The in vivo antioxidant effect of PEOR increased with the increase of dose; $400 \mathrm{mg} / \mathrm{kg}$ is a promising dose deserved to be further studied; in this dose, PEOR also shows antifatigue effect. There are six amino acids with hydrogen-donor side chains, eight antioxidant amino acids, and twelve glucogenic amino acids present in PEOR; they may play an important role in exertion of the in vitro and in vivo antioxidant activity, as well as the in vivo antifatigue effect of PEOR.

\section{Conflicts of Interest}

The authors declare no conflict of interest.

\section{Authors' Contributions}

Hongli Zhou and Yang Zhang conceived and designed the experiments; Yang Liu performed the in vivo antioxidant evaluation; Kun Zhu determined the biochemical indicators; Yao Dong conducted the in vitro antioxidant evaluation; Hao
Cui prepared and analyzed PEOR; Liping Mao and Xiaoxiao $\mathrm{Xu}$ did the in vivo antifatigue evaluation; Yang Zhang analyzed the data and wrote the manuscript, and Hongli Zhou revised it.

\section{Acknowledgments}

This study was financed by the Program of Jilin Provincial Science and Technology Department (Grant no. 20150311044YY) and the Scientific Foundation of Jilin Institute of Chemical Technology (Grant no. 2016032, 2017013). The authors also express their gratitude to Dr. Ling Qi, Jilin Medical University, for her work on histopathological examination and Dr. Yawen Gu, Hebei University of Science and Technology, for her work on the analysis of amino acid composition.

\section{References}

[1] S. Srivastava, D. Singh, S. Patel, and M. R. Singh, "Role of enzymatic free radical scavengers in management of oxidative stress in autoimmune disorders," International Journal of Biological Macromolecules, vol. 101, pp. 502-517, 2017.

[2] J. Martinez-Useros, W. Li, M. Cabeza-Morales, and J. GarciaFoncillas, "Oxidative stress: a new target for pancreatic cancer prognosis and treatment," Journal of Clinical Medicine, vol. 6, no. 3, p. 29, 2017.

[3] H. C. Lee and Y. H. Wei, "Mitochondrial alterations, cellular response to oxidative stress and defective degradation of proteins in aging," Biogerontology, vol. 2, no. 4, pp. 231244, 2001.

[4] N. Khansari, Y. Shakiba, and M. Mahmoudi, "Chronic inflammation and oxidative stress as a major cause of age-related diseases and cancer," Recent Patents on Inflammation \& Allergy Drug Discovery, vol. 3, no. 1, pp. 73-80, 2009.

[5] D. Romero-Alvira and E. Roche, "The keys of oxidative stress in acquired immune deficiency syndrome apoptosis," Medical Hypotheses, vol. 51, no. 2, pp. 169-173, 1998.

[6] R. Lee Mosley, E. J. Benner, I. Kadiu et al., "Neuroinflammation, oxidative stress and the pathogenesis of Parkinson's disease," Clinical Neuroscience Research, vol. 6, no. 5, pp. 261-281, 2006.

[7] G. E. Gibson and H. M. Huang, "Oxidative stress in Alzheimer's disease," Neurobiology of Aging, vol. 26, no. 5, pp. 575578, 2005.

[8] V. Sosa, T. Moliné, R. Somoza, R. Paciucci, H. Kondoh, and M. E. LLeonart, "Oxidative stress and cancer: an overview," Ageing Research Reviews, vol. 12, no. 1, pp. 376-390, 2013.

[9] D. Szuroczki, J. Koprivnikar, and R. L. Baker, "Dietary antioxidants enhance immunocompetence in larval amphibians," Comparative Biochemistry and Physiology Part A: Molecular \& Integrative Physiology, vol. 201, pp. 182-188, 2016.

[10] A. Singh, P. S. Naidu, S. Gupta, and S. K. Kulkarni, "Effect of natural and synthetic antioxidants in a mouse model of chronic fatigue syndrome," Journal of Medicinal Food, vol. 5, no. 4, pp. 211-220, 2002.

[11] L. You, M. Zhao, J. M. Regenstein, and J. Ren, "In vitro antioxidant activity and in vivo anti-fatigue effect of loach (Misgurnus anguillicaudatus) peptides prepared by papain digestion," Food Chemistry, vol. 124, no. 1, pp. 188-194, 2011. 
[12] J. C. Lee, J. Y. Kao, D. H. Kuo et al., "Antifatigue and antioxidant activity of alcoholic extract from Saussurea involucrata," Journal of Traditional and Complementary Medicine, vol. 1, no. 1, pp. 64-68, 2011.

[13] Z. Guo, D. Lin, J. Guo, Y. Zhang, and B. Zheng, "In vitro antioxidant activity and in vivo anti-fatigue effect of sea horse (hippocampus) peptides," Molecules, vol. 22, no. 3, p. 482, 2017.

[14] J. Xu, Y. Li, J. Regenstein, and X. Su, "In vitro, and in vivo, antioxidation and anti-fatigue effect of monkfish liver hydrolysate," Food Bioscience, vol. 18, pp. 9-14, 2017.

[15] H. A. Scheraga, "Protein structure and function, from a colloidal to a molecular view," Carlsberg Research Communications, vol. 49, no. 1, pp. 1-55, 1984.

[16] M. Sivapriya and S. Leela, "Isolation and purification of a novel antioxidant protein from the water extract of Sundakai (Solanum torvum) seeds," Food Chemistry, vol. 104, no. 2, pp. 510-517, 2007.

[17] Ž. Vaštag, L. Popović, S. Popović, L. Petrović, and D. Peričin, "Antioxidant and angiotensin-I converting enzyme inhibitory activity in the water-soluble protein extract from Petrovac Sausage (Petrovská Kolbása)," Food Control, vol. 21, no. 9, pp. 1298-1302, 2010.

[18] Z. Wang, Y. Liu, H. Li, and L. Yang, "Rice proteins, extracted by alkali and $\alpha$-amylase, differently affect in vitro antioxidant activity," Food Chemistry, vol. 206, pp. 137-145, 2016.

[19] L. L. Jin, S. S. Song, Q. Li, Y. H. Chen, Q. Y. Wang, and S. T. Hou, "Identification and characterisation of a novel antimicrobial polypeptide from the skin secretion of a Chinese frog (Rana chensinensis)," International Journal of Antimicrobial Agents, vol. 33, no. 6, pp. 538-542, 2009.

[20] Y. Qi, B. Lu, H. Gao, P. Hu, and J. Fu, "Hybridization and mitochondrial genome introgression between Rana chensinensis and R. kukunoris," Molecular Ecology, vol. 23, no. 22, pp. 5575-5588, 2014.

[21] Y. Zhang, K. Zhu, H. Cui et al., "Toxicological evaluation of Oviductus ranae: acute, sub-acute and genotoxicity studies in mice and rats," Journal of Ethnopharmacology, vol. 203, pp. 101-109, 2017.

[22] J. Xiao and D. Jiang, "On origin of Oviductus ranae in Chinese pharmacopoeia," Zhongguo Zhong Yao Za Zhi, vol. 35, no. 21, pp. 2931-2933, 2010.

[23] Y. Wang, L. Wang, Y. Hu, L. Zhang, and Z. Wang, "Isolation and identification of two steroid compounds from Oviductus ranae," Natural Product Research, vol. 24, no. 16, pp. 1518$1522,2010$.

[24] D. Huang, L. Yang, C. Wang et al., "Immunostimulatory activity of protein hydrolysate from Oviductus ranae on macrophage in vitro," Evidence-based Complementary and Alternative Medicine, vol. 2014, Article ID 180234, 11 pages, 2014.

[25] L. Liang, X. H. Zhang, Y. Zhou, Y. J. Huang, and H. Z. Deng, "Protective effect of Oviductus ranae capsules on the reproductive organs of aged mice," Nan Fang Yi Ke Da Xue Xue Bao, vol. 28, no. 6, pp. 982-985, 2008.

[26] P. Zhang, H. Ge, Y. Lai, and L. Zhang, "Effect of Oviductus rana on alleviating physical fatigue in rats," Wei Sheng Yan Jiu, vol. 40, no. 2, pp. 231-232, 2011.

[27] X. M. Ling, X. H. Zhang, Y. Tan et al., "Protective effects of Oviductus ranae-containing serum on oxidative stressinduced apoptosis in rat ovarian granulosa cells," Journal of Ethnopharmacology, vol. 208, pp. 138-148, 2017.
[28] D. H. Wang, W. Wu, J. M. Tian et al., "Effect of Oviductus ranae and Oviductus ranae eggs on bone metabolism and osteoporosis," Chinese Journal of Integrative Medicine, vol. 19, no. 7, pp. 532-538, 2013.

[29] L. Kang, N. Li, and D. C. Jiang, "Estrogen-like effects of Oviductus ranae," Modern Food Science and Technology, vol. 31, no. 8, pp. 25-31, 2015.

[30] D. T. Wang and D. H. Wang, "Chemical constituents and pharmacological activities of Oviductus ranae," Journal of Changchun University of Chinese Medicine, vol. 31, no. 6, pp. 1127-1129, 2015.

[31] E. Ichiishi, X. K. Li, and E. L. Iorio, "Oxidative stress and diseases: clinical trials and approaches," Oxidative Medicine and Cellular Longevity, vol. 2016, Article ID 3458276, 3 pages, 2016.

[32] A. Matkowski, W. Jamiołkowska-Kozlowska, and I. Nawrot, "Chinese medicinal herbs as source of antioxidant compounds - where tradition meets the future," Current Medicinal Chemistry, vol. 20, no. 8, pp. 984-1004, 2013.

[33] M. M. Bradford, "A rapid and sensitive method for the quantitation of microgram quantities of protein utilizing the principle of protein-dye binding," Analytical Biochemistry, vol. 72, no. $1-2$, pp. 248-254, 1976.

[34] X. Wang, R. Xing, Z. Chen, H. Yu, R. Li, and P. Li, "Effect and mechanism of mackerel (Pneumatophorus japonicus) peptides for anti-fatigue," Food \& Function, vol. 5, no. 9, pp. 2113-2119, 2014.

[35] N. Shaheen, S. Islam, S. Munmun, M. Mohiduzzaman, and T. Longvah, "Amino acid profiles and digestible indispensable amino acid scores of proteins from the prioritized key foods in Bangladesh," Food Chemistry, vol. 213, pp. 83-89, 2016.

[36] W. Sun, H. Zhao, Q. Zhao et al., "Structural characteristics of peptides extracted from Cantonese sausage during drying and their antioxidant activities," Innovative Food Science \& Emerging Technologies, vol. 10, no. 4, pp. 558-563, 2009.

[37] OECD, Test Guideline 423: Acute Oral Toxicity-Acute Toxic Class Method, OECD Guideline for the Testing of Chemicals, Paris, France, 2001.

[38] L. You, M. Zhao, R. H. Liu, and J. M. Regenstein, “Antioxidant and antiproliferative activities of loach (Misgurnus anguillicaudatus) peptides prepared by papain digestion," Journal of Agricultural and Food Chemistry, vol. 59, no. 14, pp. 79487953, 2011.

[39] Y.-W. Liu, C.-H. Han, M.-H. Lee, F.-L. Hsu, and W.-C. Hou, "Patatin, the tuber storage protein of potato (Solanum tuberosum L.), exhibits antioxidant activity in vitro," Journal of Agricultural and Food Chemistry, vol. 51, no. 15, pp. 4389-4393, 2003.

[40] R. Li, H. Yu, R. Xing et al., "Isolation, identification and characterization of a novel antioxidant protein from the nematocyst of the jellyfish Stomolophus meleagris," International Journal of Biological Macromolecules, vol. 51, no. 3, pp. 274278, 2012.

[41] K. Z. Peng, X. Yang, H. L. Zhou, and S. X. Pan, "Safety evaluation, in vitro and in vivo antioxidant activity of the flavonoidrich extract from Maydis stigma," Molecules, vol. 20, no. 12, pp. 22102-22112, 2015.

[42] Y. Zhang, H. Sun, Z. Liu, and H. L. Zhou, "Antioxidant effect of perilla oil on ethanol-induced oxidative stress in mice," Food Science, vol. 36, no. 23, pp. 279-282, 2015. 
[43] H. P. Zhao, Y. Zhang, Z. Liu et al., "Acute toxicity and antifatigue activity of polysaccharide-rich extract from corn silk," Biomedicine \& Pharmacotherapy, vol. 90, pp. 686-693, 2017.

[44] Y. Lin, H. L. Liu, J. Fang, C. H. Yu, Y. K. Xiong, and K. Yuan, "Anti-fatigue and vasoprotective effects of quercetin-3-O-gentiobiose on oxidative stress and vascular endothelial dysfunction induced by endurance swimming in rats," Food and Chemical Toxicology, vol. 68, pp. 290-296, 2014.

[45] R. R. Dalefield and F. W. Oehme, "Deer velvet antler: some unanswered questions on toxicology," Veterinary and Human Toxicology, vol. 41, no. 1, pp. 39-41, 1999.

[46] C. Kostakis and R. W. Byard, "Sudden death associated with intravenous injection of toad extract," Forensic Science International, vol. 188, no. 1-3, pp. e1-e5, 2009.

[47] A. S. Karadag, O. Calka, N. Akdeniz, and I. Cecen, "A case of irritant contact dermatitis with leech," Cutaneous and Ocular Toxicology, vol. 30, no. 3, pp. 234-235, 2011.

[48] S. E. L. T. Menegati, F. Freitas de Lima, G. K. Traesel et al., "Acute and subacute toxicity of the aqueous extract of Alibertia edulis (Rich.) A. Rich. ex DC. in rats," Journal of Ethnopharmacology, vol. 194, pp. 1096-1102, 2016.

[49] P. Raina, C. V. Chandrasekaran, M. Deepak, A. Agarwal, and K. G. Ruchika, "Evaluation of subacute toxicity of methanolic/aqueous preparation of aerial parts of $O$. sanctum in Wistar rats: clinical, haematological, biochemical and histopathological studies," Journal of Ethnopharmacology, vol. 175, pp. 509$517,2015$.

[50] E. R. Stadtman, "Oxidation of free amino acids and amino acid residues in proteins by radiolysis and by metal-catalyzed reactions," Annual Review of Biochemistry, vol. 62, no. 1, pp. 797-821, 1993.

[51] B. Wang, L. Li, C. F. Chi, J. H. Ma, H. Y. Luo, and Y. F. $\mathrm{Xu}$, "Purification and characterisation of a novel antioxidant peptide derived from blue mussel (Mytilus edulis) protein hydrolysate," Food Chemistry, vol. 138, no. 2-3, pp. 1713$1719,2013$.

[52] H. M. Habte-Tsion, M. Ren, B. Liu, X. Ge, J. Xie, and R. Chen, "Threonine modulates immune response, antioxidant status and gene expressions of antioxidant enzymes and antioxidant-immune-cytokine-related signaling molecules in juvenile blunt snout bream (Megalobrama amblycephala)," Fish \& Shellfish Immunology, vol. 51, pp. 189-199, 2016.

[53] M. Oh, E. K. Kim, B. T. Jeon et al., "Chemical compositions, free amino acid contents and antioxidant activities of Hanwoo (Bos taurus coreanae) beef by cut," Meat Science, vol. 119, pp. 16-21, 2016.

[54] A. Saiga, S. Tanabe, and T. Nishimura, "Antioxidant activity of peptides obtained from porcine myofibrillar proteins by protease treatment," Journal of Agricultural and Food Chemistry, vol. 51, no. 12, pp. 3661-3667, 2003.

[55] L. Wang, H. L. Zhang, R. Lu et al., "The decapeptide CMS001 enhances swimming endurance in mice," Peptides, vol. 29, no. 7, pp. 1176-1182, 2008.

[56] S. K. Powers, K. C. Deruisseau, J. Quindry, and K. L. Hamilton, "Dietary antioxidants and exercise," Journal of Sports Sciences, vol. 22, no. 1, pp. 81-94, 2004.

[57] M. Tanaka, F. Nakamura, S. Mizokawa, A. Matsumura, S. Nozaki, and Y. Watanabe, "Establishment and assessment of a rat model of fatigue," Neuroscience Letters, vol. 352, no. 3, pp. 159-162, 2003.
[58] V. Ganapathy, "Chapter 59 - protein digestion and absorption," Physiology of the Gastrointestinal Tract (Fifth edition), vol. 2, pp. 1595-1623, 2012.

[59] K. E. Webb Jr, "Intestinal absorption of protein hydrolysis products: a review," Journal of Animal Science, vol. 68, no. 9, pp. 3011-3022, 1990. 


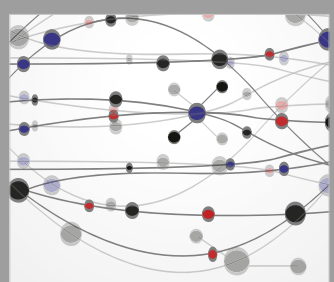

The Scientific World Journal
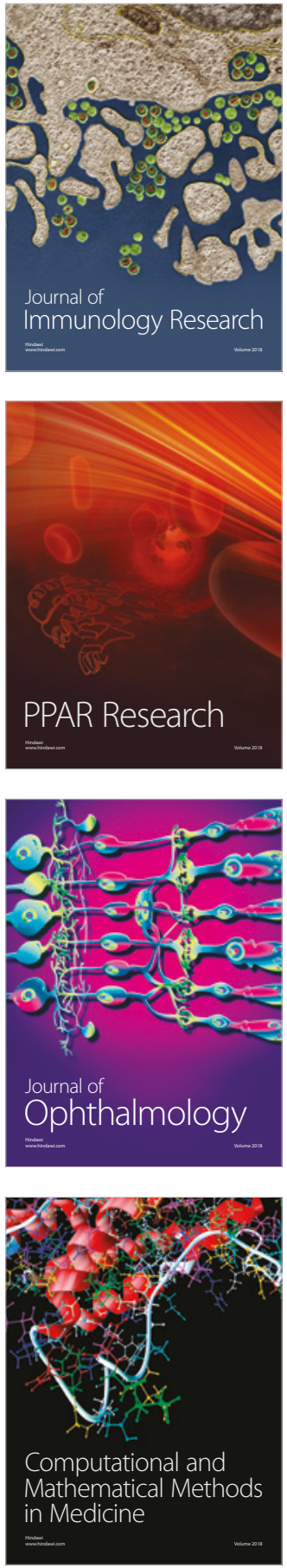

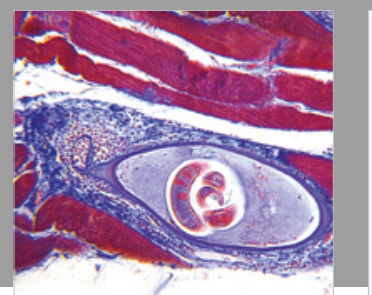

Gastroenterology Research and Practice

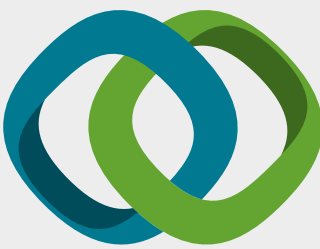

\section{Hindawi}

Submit your manuscripts at

www.hindawi.com
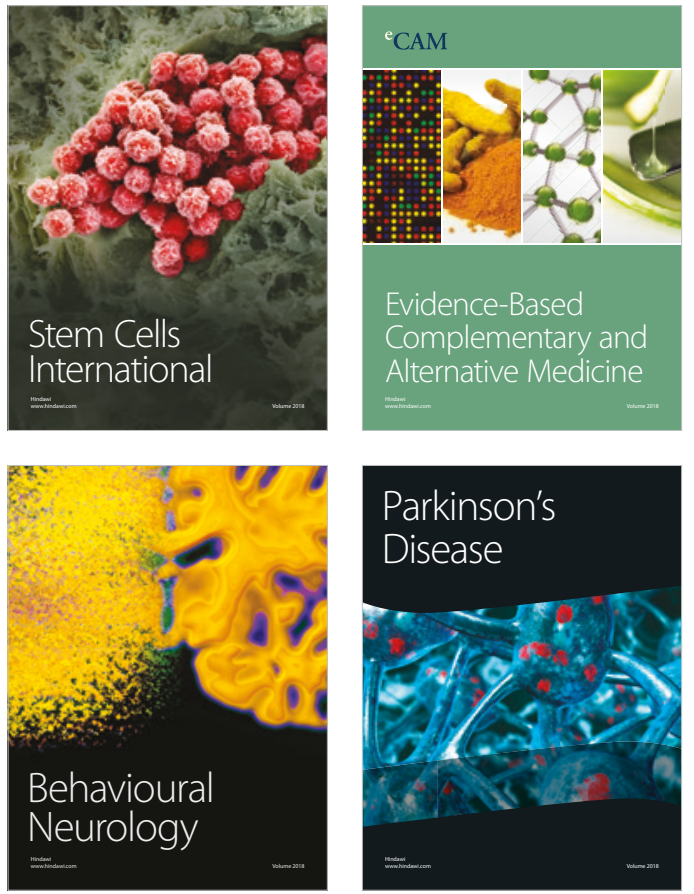

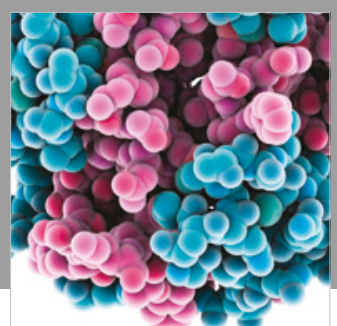

ournal of

Diabetes Research

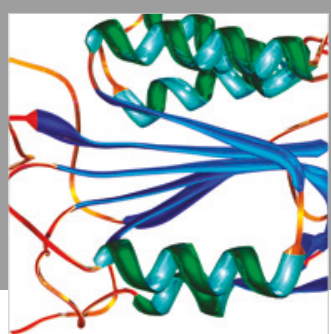

Disease Markers
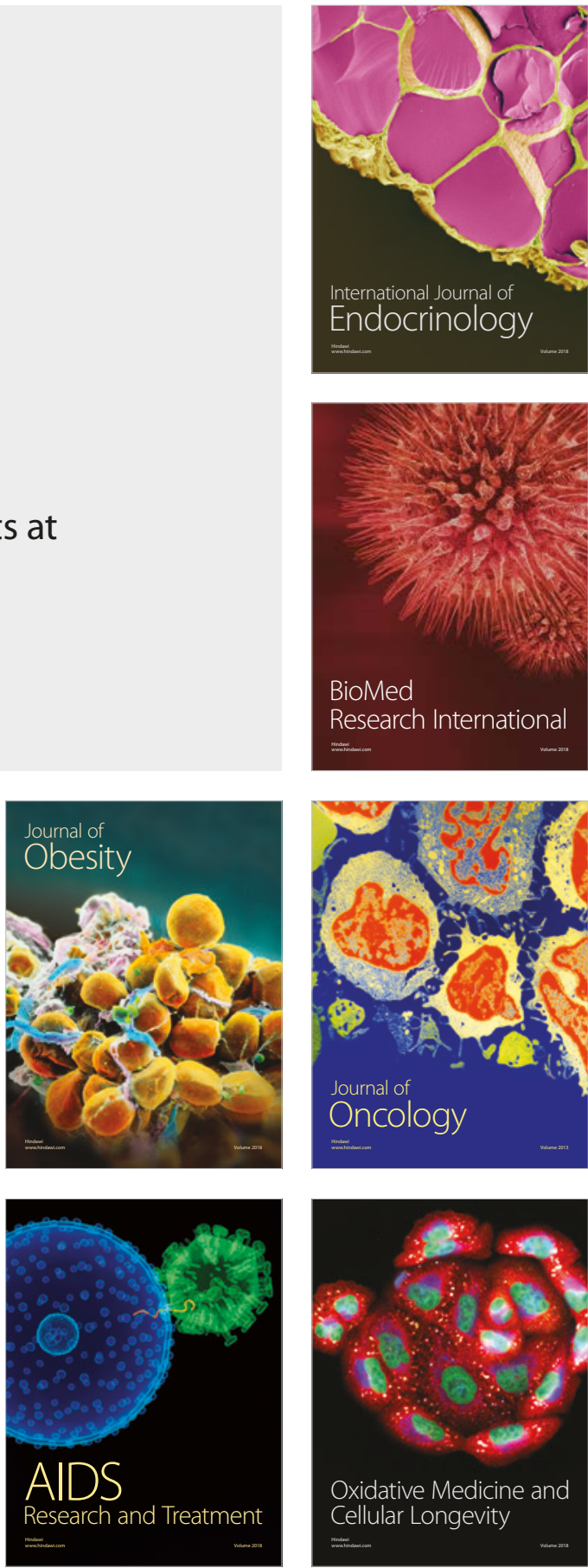